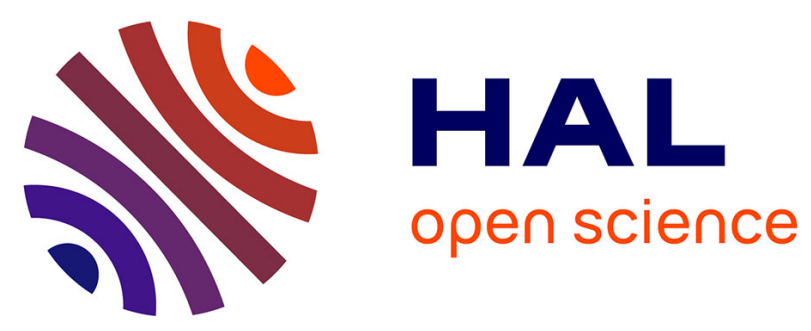

\title{
Wood washing: influence on gaseous and particulate emissions during wood combustion in a domestic pellet stove
}

Guillaume Schmidt, Gwenaëlle Trouvé, Gontrand Leyssens, Cornelius Schönnenbeck, Paul Genevray, Fabrice Cazier, Dorothée Dewaele, Coralie Vandenbilcke, Elodie Faivre, Yann Denance, et al.

\section{To cite this version:}

Guillaume Schmidt, Gwenaëlle Trouvé, Gontrand Leyssens, Cornelius Schönnenbeck, Paul Genevray, et al.. Wood washing: influence on gaseous and particulate emissions during wood combustion in a domestic pellet stove. Fuel Processing Technology, 2018, 174, pp.104-117. 10.1016/j.fuproc.2018.02.020 . hal-02394402

\section{HAL Id: hal-02394402 \\ https://hal-cstb.archives-ouvertes.fr/hal-02394402}

Submitted on 4 Dec 2019

HAL is a multi-disciplinary open access archive for the deposit and dissemination of scientific research documents, whether they are published or not. The documents may come from teaching and research institutions in France or abroad, or from public or private research centers.
L'archive ouverte pluridisciplinaire HAL, est destinée au dépôt et à la diffusion de documents scientifiques de niveau recherche, publiés ou non, émanant des établissements d'enseignement et de recherche français ou étrangers, des laboratoires publics ou privés. 


\section{Wood washing: Influence on gaseous and particulate emissions during wood combustion in a domestic pellet stove}

Guillaume Schmidta, Gwenaëlle Trouvéa, Gontrand Leyssensa, Cornelius Schönnenbeck ${ }^{\mathrm{a}}$, Paul Genevray $^{\mathrm{b}}$, Fabrice Cazier ${ }^{\mathrm{b}}$, Dorothée Dewaele ${ }^{\mathrm{b}}$, Coralie Vandenbilcke ${ }^{\mathrm{b}}$, Elodie Faivre ${ }^{\mathrm{c}}$, Yann Denance $^{\mathrm{c}}$, Céline Le Dreff-Lorimier ${ }^{d}$

a Laboratoire Gestion des Risques et Environnement - Université de Haute-Alsace, 3b rue Alfred WERNER, 68093 Mulhouse Cedex, France

b Centre Commun de Mesures, Université du Littoral Côte d'Opale, 145 avenue Maurice Schumann, 59140 Dunkerque, France

c INOVALP, 38350 La Mure, France

d CSTB, 44300 Nantes, France

Corresponding author: gwenaelle.trouve@uha.fr

\section{Abstract}

Nowadays, the use of biomass increasingly replaces the fossil fuels for the domestic heating production. In order to reduce pollutant emissions from biomass combustion, wood was washed at room temperature in order to represent natural rain leaching before burning in a recent pellet stove (2010s) of nominal output of $6.3 \mathrm{~kW}$. Raw and washed woods were combusted for three different types of wood (oak, beech and fir) and the study focused on their particulate and gaseous emissions (Total Suspended Particles (TSP), Particulate Matter with diameter below $2.5 \mu \mathrm{m}\left(\mathrm{PM}_{2.5}\right)$, carbon monoxide (CO), nitrogen oxides (NOx) and Total Volatile Organic Compounds (TVOC)). Polycyclic Aromatic Hydrocarbons (PAH), aldehydes and wood tracers as phenols compounds were also measured. In addition, considering the toxic equivalent factor, the human health impact of adsorbed and gaseous PAH is considerably reduced (96\%) in the case of washed fir combustion. Emission factors of CO and TSP for washed wood combustion also show a decrease up to $50 \%$ depending on the type of wood used. Furthermore, phenolic compounds, Benzene, Toluene, Ethylbenzene, Xylenes and Trimethylbenzene (BTEXT) emissions can also be reduced by the washing of biomass. Washed oak combustion leads to a clear decrease by $60 \%$ of the total of BTEXT. In the case of phenols emissions, phenol shows a significant decrease by $91 \%$ during the combustion of washed fir wood.

Keywords

Wood washing; Combustion; Pellet stove; Gaseous emissions; Particulate matter

\section{Introduction}

Wood pellets have become an important fuel in domestic heat generation, since the costs of fossil fuels are rising and the emissions are nearly $\mathrm{CO}_{2}$ neutral. All households are incited to turn to the use of biomass as energy source for domestic heating. In contrast to other wood based fuels, the utilization of pellets is easy and automatic feeding to stoves and boiler is possible. Furthermore, the pelletization densifies the wood and produces a fuel with high energetic density [1]. On the one hand, wood pellets are a convenient choice for domestic fuel because of its simplicity of implementation and its low cost [2]. But on the other hand, wood pellets combustion, and more generally wood combustion, is a source of fine particles $\left(\mathrm{PM}_{2.5}\right)$ and gaseous compounds as carbon monoxide (CO) or other incomplete combustion gas as nitrogen oxides (NOx) or Non-Methane Volatile Organic Compounds (NMVOC) [[3], [4], [5], [6], [7], [8]]. But most emissions from pellets combustion are lower than wood log combustion 
$[3,9]$ because in the case of wood logs, parameters as wood species, humidity could disfavor the combustion process and generate big amounts of incomplete combustion products. As example, pollutant emissions from wood log combustion in domestic devices (open and closed fireplaces, traditional and advanced stoves) range from 20 and $120 \mathrm{~g} \cdot \mathrm{kg}^{-1}$ for $\mathrm{CO}$, are close to $1 \mathrm{~g} \cdot \mathrm{kg}^{-1}$ for NOx, range from 2 to $20 \mathrm{~g} \cdot \mathrm{kg}^{-1}$ for NMVOC and range from 0.2 to $2 \mathrm{~g} \cdot \mathrm{kg}^{-1}$ for PM emissions [[3], [4], [5], [6]]. The high magnitude of emissions from small domestic devices well depends on several parameters as fuel quality and operating conditions (wall material of the combustion chamber, natural draft, primary and/or secondary air, operational practices, etc.). Whereas values from pellets combustion range from 1 to $5 \mathrm{~g} \cdot \mathrm{kg}^{-1}$ for $\mathrm{CO}$, are close to $1 \mathrm{~g} \cdot \mathrm{kg}^{-1}$ for NOx, range from 60 to $100 \mathrm{mg} \cdot \mathrm{kg}^{-1}$ for NMVOC and range from 0.2 to $0.5 \mathrm{~g} \cdot \mathrm{kg}^{-1}$ for PM emissions $[3,7,8]$. More generally, combustion of wood pellets, due to a better complete combustion, is clearly less emissive in comparison with wood logs combustion. The automatic feed of the fuel and the possible presence of a lambda probe are advanced technologies that contribute to complete combustion $[7,8]$.

In the last decade, numerous studies were devoted to the evaluation of emission factors for gaseous compounds or particulate matter from residential wood combustion appliances $[3,8,10]$. The main gaseous pollutants usually followed from wood combustion are carbon monoxide, Volatile Organic Compounds (VOCs) [8]. Trace pollutants as Polycyclic Aromatic Hydrocarbons, benzene, toluene, ethylbenzene, xylenes, trimethylbenzene (BTEXT), phenols, aldehydes and ketones are often analyzed too $[3,10]$. Phenol and methoxy-phenols as syringol and guaiacol are also used as tracers of wood combustions [11]. Regarding particulate emissions, Total Suspended Particles (TSP) and PM $_{2.5}$ are constantly measured because it is well known that wood burning is one of the most emitting sources of fine particles $[3,9,12]$.

Nowadays, several techniques are developed in order to reduce pollutants from wood combustion. Primary and secondary technologies must be distinguished: on the one hand, primary solutions focus on fuel quality and the conception of stoves and boilers, on the other hand, secondary solutions focus on the post-treatment of fumes [[13], [14], [15]]. Secondary technologies largely dominate using technologies as electrostatic filter, catalytic filter, or cyclones $[16,17]$. Secondary technologies aim principally at reducing particles emissions, but some techniques as catalytic filter allow to reduce gaseous emissions as carbon monoxide and VOCs [17]. Concerning primary techniques, important efforts from the 2000s were done in order to complain with different National and European standards [[18], [19], [20], [21]] in terms of conception of stoves and boilers [22], choice of wood species and optimization of the air/fuel ratio [23]. One of the primary solutions to reduce pollutant emissions from biomass combustion could be a washing pre-treatment of wood. Indeed, by washing wood, some compounds as minerals or extractives from wood could be removed. Deng et al. [24] have studied demineralization of some biomasses by a washing process with deionized water at temperatures ranging from $30^{\circ} \mathrm{C}$ to $90^{\circ} \mathrm{C}$ and results show that minerals as potassium or calcium could be extracted. For example from rice straw, extraction efficiency reaches respectively 87 and $19 \%$ at $30^{\circ} \mathrm{C}$ for both elements. Jiang et al. [25] have also studied rice straw demineralization by several solvents as deionized water, chloride acid or phosphoric acid for example. Results show that, depending on the solvent, demineralization efficiency varies: calcium can be removed by $17 \%$ using deionized water versus $98 \%$ using chloride acid. Some extractives as phenols or carboxylic acids are also removed by wood washing [[25], [26], [27]].

Most of the studies have attempted to compare pollutant emissions as a function of the nature of the wood or the technology of the domestic heating appliances [22,23]. Main literature data focused on the influence of demineralization process on devolatilization phases of lignocellulosic polymers during thermogravimetric analysis $[24,25,28]$. Investigations on the influence of the wood preparation, particularly the washing process on gaseous and particulate pollutants emitted in the exhaust are scarce at real domestic scale [28]. This study aims at studying the leaching at room temperature of woods and their combustion (raw and washed biomasses) in a pellet stove to observe variations of 
gaseous and particulate emissions thanks to demineralization of wood. This work is a preliminary study of a French project supported by the National Agency of Energy and Environment (ADEME). The ultimate goal of this project is to study the influence of the natural leaching by rain of wood logs stored outside in forest for several months to a few years on gaseous and particulate pollutants during combustion in domestic devices as inserts and stoves. In order to get free of the variability due to the wood log fuel, it was decided to study the influence of leaching at laboratory scale using a pellet stove. Wood chips were then washed using demineralized water before preparing wood pellets. The stabilized conditions of a pellet burning system allow the detection of even small differences between different fuel types. This preliminary study on pellets washing aims to really understand and clearly explain the role of leaching on wood combustion with respect to gaseous and particulate emissions. Combustion of natural leached wood logs in a domestic stove will follow in a near future in order to compare these results.

\section{Experimentals}

\subsection{Washing and pelletization protocols}

Washing and pelletization protocols of biomasses are schematized in Fig. 1. Pre-treatment of beech, oak and fir chips was carried out at laboratory in a pilot according to the standard leaching protocol EN 12457/2 of May 2002 [29]. A quantity of $20 \mathrm{~kg}$ of dried wood chips was introduced into the pilot filled with $200 \mathrm{I}$ of deionized water and mechanically shaken for $6 \mathrm{~h}$. This operation was repeated three times but without drying wood samples between each cycle. For each cycle, the washing water is analyzed by ICP/OES (Thermo Scientific model ICAP 6300 DUO) for the quantification of minerals. The Total Organic Carbon (TOC) of residual leached solutions for $24 \mathrm{~h}$ was determined by catalytic oxidation of the organic carbon into dioxide carbon using a SHIMADZU TOC-VCSN apparatus. The moisture content of all raw and washed biomasses was brought to about $12 \mathrm{wt} \%$ (wet basis). Biomass chips were then ground and pelletized by a pellet press KAHL 14/175 equipped with a die having channels of $6 \mathrm{~mm}$ diameter and 22 or $26 \mathrm{~mm}$ length. Natural wood pellets with diameter close to $6 \mathrm{~mm}$ (purchased from SOFAG company, Arc sous Cicon, France) according to the DIN CERTCO standard were used as a reference during combustion tests [30].

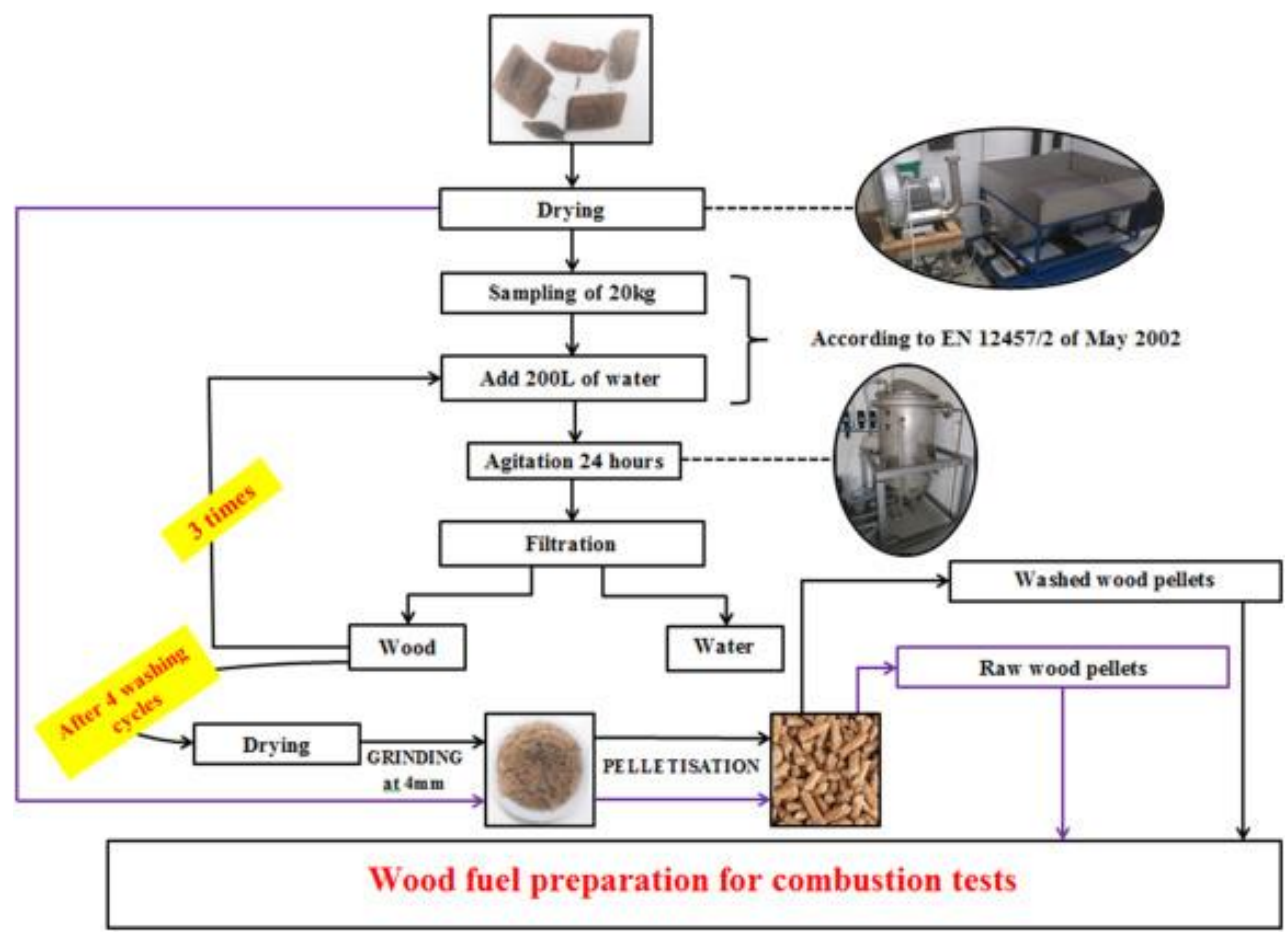

Fig. 1. Wood fuel preparation for combustion tests. 


\subsection{Characterization of wood pellet samples}

According to Table 1, the weight fractions of the different elements are in the same order of magnitude than those found for raw biomasses and lignocellulosic materials in literature [31]. The leaching process does not really affect elemental values CHONS. Both raw and washed woods show values having the same order of magnitude. $\mathrm{O} / \mathrm{C}$ and $\mathrm{H} / \mathrm{C}$ atomic ratio values are close to 0.7 and 1.5 respectively, according to Van Krevelen diagram defining biomasses [[32], [33], [34]]. A slightly decrease of the $\mathrm{O} / \mathrm{C}$ ratios is observed for washed fir and oak, due to the dissolution of labile oxygen organic molecules as extractives (phenols, carboxylic acids, simple sugars, glycosides, fats, etc.) during the washing procedure $[25,27]$. This loss of organic molecules impacts the LHV as seen in Table 1 . The leaching process also extracts low amounts of TOC as shown in Table 1. Oak is well-known to be a hard wood specie that contains higher amounts of tannins [35]. Biochemical composition of wood pellets was determined according the Van Soest's protocol [36] and results are given in Table 1 and are discussed in the following text (part 3).

Table 1. Physical and chemical properties of the raw and washed wood species.

\begin{tabular}{|c|c|c|c|c|c|c|c|}
\hline \multirow{2}{*}{ Properties/woods } & \multirow{2}{*}{$\begin{array}{l}\text { DIN } \\
\text { Certco }\end{array}$} & \multicolumn{2}{|l|}{ Fir } & \multicolumn{3}{|l|}{ Beech } & \multirow{2}{*}{$\begin{array}{l}\text { Oak } \\
\text { Washed }\end{array}$} \\
\hline & & Raw & Washed & Raw & Washed & Raw & \\
\hline Humidity $\left.{ }^{\mathrm{a}} \%\right)$ & 9 & 12 & 14 & 9 & 11 & 11 & 9 \\
\hline Ash content ${ }^{b, c}(\%)$ & 0.30 & 0.40 & 0.30 & 1.05 & 0.71 & 0.87 & 0.54 \\
\hline$C^{b}(\%)$ & 47.1 & 46.4 & 48.6 & 46.3 & 47.8 & 46.3 & 47.6 \\
\hline $\mathrm{H}^{\mathrm{b}}(\%)$ & 6.1 & 5.7 & 6.0 & 6.0 & 6.0 & 5.7 & 6.1 \\
\hline$N^{b}(\%)$ & $<0.1$ & $<0.1$ & $<0.1$ & $<0.1$ & $<0.1$ & $<0.1$ & $<0.1$ \\
\hline $0^{b}(\%)$ & 46.6 & 41.0 & 41.3 & 43.1 & 43.7 & 40.9 & 39.8 \\
\hline$S^{b}(\%)$ & $<0.03$ & $<0.03$ & $<0.03$ & $<0.03$ & $<0.03$ & $<0.03$ & $<0.03$ \\
\hline$H H V^{b, d}\left(M J \cdot k^{-1}\right)$ & 18.8 & 20.0 & 17.3 & 18.6 & 17.4 & 18.2 & 17.8 \\
\hline $\mathrm{LHV}^{\mathrm{b}, \mathrm{e}}\left(\mathrm{MJ} \cdot \mathrm{kg}^{-1}\right)$ & 17.2 & 18.8 & 15.7 & 17.5 & 15.9 & 17.1 & 16.3 \\
\hline$H / C^{f}$ & 1.55 & 1.47 & 1.48 & 1.55 & 1.50 & 1.47 & 1.53 \\
\hline$O / C^{f}$ & 0.74 & 0.66 & 0.63 & 0.69 & 0.68 & 0.66 & 0.62 \\
\hline Extractives $(\%)^{\mathrm{b}, \mathrm{g}}$ & 10 & 8 & 4 & 12 & 10 & 19 & 7 \\
\hline Hemicellulose $(\%)^{b, g}$ & 19 & 21 & 17 & 27 & 25 & 21 & 25 \\
\hline Cellulose $(\%)^{b, g}$ & 44 & 43 & 50 & 40 & 50 & 45 & 54 \\
\hline Lignin $(\%)^{b, g}$ & 27 & 28 & 29 & 21 & 15 & 14 & 14 \\
\hline TOC $\left(g \cdot \mathrm{kg}^{-1}\right)^{\mathrm{b}, \mathrm{h}}$ & n.di & 0.62 & & 0.65 & & & 1.41 \\
\hline
\end{tabular}

\footnotetext{
a On raw basis.

b On dried basis.

c Measured at $550^{\circ} \mathrm{C}$.

d HHV for High Heating Value.

e $\quad$ LHV for Low Heating Value.

f $\quad \mathrm{H} / \mathrm{C}$ and $\mathrm{O} / \mathrm{C}$ are atomic ratios according to Van Krevelen [32].

$\mathrm{g} \quad$ Biochemical composition was performed according the Van Soest protocol [36].

$\mathrm{h}$ COT were measured in residual leached solution after a leaching process for $24 \mathrm{~h}$ at room temperature.

i n.d: non determined.
} 
Washing or leaching proceeds to demineralization of the wood with very high removal efficiencies of some minerals as potassium, sodium, calcium, sulfur and phosphor $[24,28]$. Raw and washed biomasses have been analyzed by ICP/OES (Thermo Scientific model ICAP 6300 DUO). Table 2 shows values of 10 main minerals contained in the raw biomasses and the percentage of extraction thereof from the washing process. Excepted for calcium removal efficiencies, values of the percentage of extraction are according to the literature $[24,25,28,37]$, main soluble elements being $\mathrm{K}, \mathrm{Na}$ and $\mathrm{P}$ with extraction balances ranging from 50 to $100 \%$ and depending of several factors as temperature, duration time and mass/volume ratios. Ratios of extraction for calcium drastically depend of its chemical speciation in the wood related to nature and the solubility of each salt $\left(\mathrm{NO}_{3}{ }^{-}, \mathrm{Cl}^{-}, \mathrm{SO}_{4}{ }^{2-}, \mathrm{HCO}_{3}{ }^{-}\right.$, $\mathrm{CO}_{3}{ }^{2-}, \mathrm{PO}_{4}{ }^{3-}$, etc.) [38].

Table 2. Minerals contents and efficiencies of the washing process.

$\begin{array}{lllllll} & \begin{array}{l}\text { Raw fir } \\ (\mathbf{m g} / \mathbf{k g})\end{array} & \begin{array}{l}\text { Fir washing } \\ \text { efficiency }\end{array} & \begin{array}{l}\text { Raw beech } \\ \text { (mg/kg) }\end{array} & \begin{array}{l}\text { Beech washing } \\ \text { efficiency }\end{array} & \begin{array}{l}\text { Raw oak } \\ \text { (mg/kg) }\end{array} & \begin{array}{l}\text { Oak washing } \\ \text { efficiency }\end{array} \\ \mathbf{A l} & 3 & -10 \% & 7 & -5 \% & 27 & -1 \% \\ \mathbf{C a} & 893 & -10 \% & 2264 & -4 \% & 3247 & -1 \% \\ \mathbf{F e} & 6 & -5 \% & 8 & -5 \% & 25 & -3 \% \\ \mathbf{K} & 279 & \pm 100 \% & 1223 & -90 \% & 991 & -70 \% \\ \mathbf{M g} & 68 & -20 \% & 386 & -13 \% & 136 & -5 \% \\ \mathbf{N a} & <5 & -80 \% & <5 & -60 \% & 6 & \pm 100 \% \\ \mathbf{P} & 18 & -59 \% & 47 & \pm 100 \% & 68 & -36 \% \\ \mathbf{S} & 50 & -58 \% & 115 & -58 \% & 158 & -7 \% \\ \mathbf{S i} & 683 & -1 \% & 194 & -36 \% & 47 & -28 \% \\ \text { Zn } & 5 & -14 \% & 2 & -4 \% & 2 & -3 \% \\ \text { Global } & / & -22 \% & / & -34 \% & / & -17 \% \\ \text { extraction } & & & & & & \end{array}$

\subsection{Combustion tests}

\subsubsection{Experimental set-up platform}

The experimental combustion setup is schematized in the Fig. 2. Combustions tests were performed in a pellet stove supplied by Hoben (Model H5 Signature Color Steel), complying with the European standard NF EN 14785 [20]. The power can be adjusted by an Intelligent Regulation System (SRI) from $1.3 \mathrm{~kW}$ to $6.3 \mathrm{~kW}$. The steel inner wall of the combustion chamber is covered by vermiculite plates in order to concentrate the heat. The pellet is fed to the burn pot by an auger system that consists of an endless screw from the refillable pellets hopper. A fan is used to force air circulation through the burn pot. The ashes migrate to the base of burner pot and are collected. 


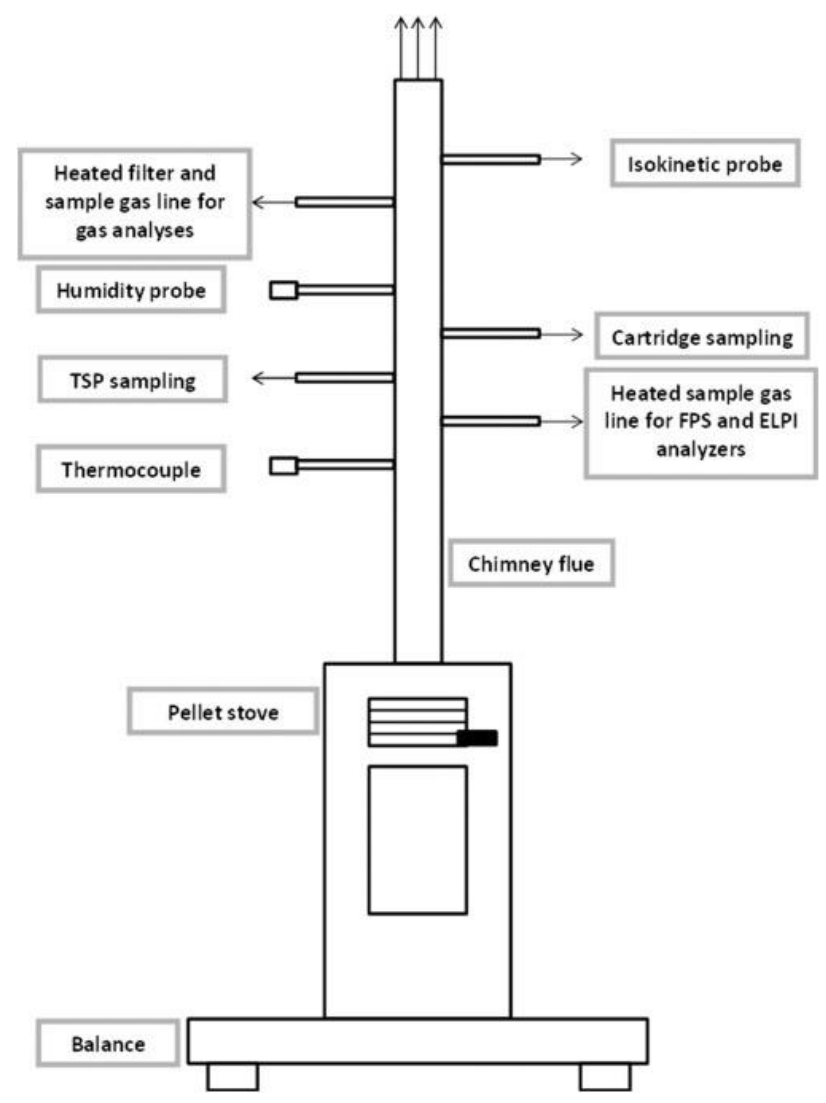

Fig. 2. Experimental combustion setup.

Each combustion test was realized for a power of $100 \%$ and a modulation of air of $50 \%$ for all wood pellet samples. Air modulation value corresponds to the rotation frequency of the pellet stove fan and so indirectly to the oxygen rate in the fumes (a linear correlation between air modulation value and oxygen rate in the fumes was observed during the tests). The air modulation value allows the adaption of the stove to the chimney and the draught during installation. Air modulation value was then determined by burning DIN+ pellets in order to obtain burning conditions and emission values according to the pellet stove manufacturer specifications. The air modulation value has been then set for all biomasses combusted in order to compare only the influence of the wood but not that of the combustion device. Ignition was accomplished using an electrical resistance. Pellets feeding rate was automatically regulated by the SRI of the stove load and the pellets consumption rate was measured during experiments thanks to a balance under the combustion platform. Emission measurements started $1 \mathrm{~h}$ after the stabilization of the combustion. This delay ensured steady state conditions and a total consumption of the initial dry combustible injected for the stove heating-up. The combustion efficiency was calculated using the NF EN 13240 standard related to stoves and boilers with a heating power lower than $50 \mathrm{~kW}$ [19]. The environmental impact of the combustion of these different biomasses was estimated using the German BImSchV level 2 regulation related to the emission control of pollutants from domestic appliances with a heating power lower than $50 \mathrm{~kW}$ and corresponding to the French label Flamme Verte 7 stars [18].

Table 3 gives the average values of combustion parameters of the pellet stove. In comparison with wood logs combustion, fume temperatures during experiments were not very high with values ranging from $162{ }^{\circ} \mathrm{C}$ to $190{ }^{\circ} \mathrm{C}$, in contrast to $230^{\circ} \mathrm{C}$ to $350^{\circ} \mathrm{C}$ for wood log combustion. These measured temperatures correspond to manufacturer specifications. These low values are related to high oxygen concentrations close to $16-17 \%$ that consequently allows significant dilution and cooling of the fumes. Values of air ratios $\lambda$ ranging from 4.8 to 6.2 highlight this observation. Moreover, a slight decrease of 
fume temperatures for washed woods is observed, except for washed oak, with standard deviations of fume temperatures being equal to only few degrees (maximum $4{ }^{\circ} \mathrm{C}$ ). In our experimental conditions, some parameters were affected by the washing process. Mass wood consumption rates decreased with washed pellets whatever the wood species. Consequently, combustion efficiency and heat output power were also lower for washed wood pellets than raw pellets. LHV of washed pellets decreased and it may explain that the heat released during combustion tests is lower compared to raw pellets. In the stove, pellets are introduced on the combustion grid by a screw working at constant volumetric flow rate. Consequently, the mass flow rate of pellets measured by the balance during the experiments, efficiency and output are significantly affected by the washing process with a decrease observed for all washed samples.

Table 3. Average values of combustion parameters.

$\begin{array}{lllllllll} & & \text { DIN+ } & \text { Fir } & \begin{array}{l}\text { Washed } \\ \text { fir }\end{array} & \text { Beech } & \begin{array}{l}\text { Washed } \\ \text { beech }\end{array} & \text { Oak } & \begin{array}{l}\text { Washed } \\ \text { oak }\end{array} \\ \mathbf{m}^{\mathbf{a}} & \left(\mathrm{kg} \cdot \mathrm{h}^{-1}\right) & 1.66 \pm 0.05 & 1.45 \pm 0.05 & 1.35 \pm 0.05 & 1.42 \pm 0.05 & 1.21 \pm 0.05 & 1.93 \pm 0.05 & 1.53 \pm 0.05 \\ \mathbf{T}_{\text {fume }} & \left({ }^{\circ} \mathrm{C}\right) & 189 & 177 & 165 & 177 & 163 & 165 & 182 \\ \mathbf{O}_{2} & (\%) & 15.7 \pm 0.1 & 16.8 \pm 0.1 & 17.4 \pm 0.1 & 16.8 \pm 0.1 & 17.5 \pm 0.1 & 17.2 \pm 0.1 & 16.3 \pm 0.1 \\ \begin{array}{l}\text { Air } \\ \text { ratio }\end{array} & \lambda & 4.8 & 5.0 & 5.9 & 5.0 & 6.2 & 5.6 & 4.5 \\ \text { Ec }^{\text {b }} & (\%) & 78.2 & 77.2 & 69.7 & 75.5 & 69.5 & 74.6 & 75.3 \\ \text { Poutput }^{c} & (\mathrm{~kW}) & 6.2 & 5.9 & 4.1 & 5.2 & 3.7 & 6.8 & 5.2\end{array}$

a Mass wood consumption rate.

b Combustion efficiency.

c Heat output power.

\subsubsection{Chemical characterization of gaseous and particulate pollutants}

Emissions were measured in the chimney during experiments at laboratory scale on the pellet stove. According to NF EN 14785 standard [20], concentrations expressed in $\mathrm{mg} \cdot \mathrm{Nm}^{-3}$ were referred to $13 \%$ of $\mathrm{O}_{2}$ in the exhaust to insure comparison for all experiments. Gaseous compounds as $\mathrm{O}_{2}, \mathrm{CO}, \mathrm{CO}_{2}$, SOx and NOx were analyzed by specific analyzers Hartmann \& Braun-Magnos $6 \mathrm{G}$ and URAS 10P and TVOC were recorded by a flame ionization detector Cosma Graphite 655 . Their concentrations were recorded for $4 \mathrm{~h}$ and their values were calculated as the mean for this time duration. TVOC were expressed in equivalent $\mathrm{CH}_{4}$.

An Electrical Low Pressure Impactor (ELPI Outdoor, version 1.2) manufactured by DEKATI Ltd. (Tampere, Finland) was used to collect particles from $7 \mathrm{~nm}$ to $10 \mu \mathrm{m}$ into 12 size fractions. The ELPI is equipped by a filtration stage with a cut-diameter of $7 \mathrm{~nm}$ and eleven impaction stages from $30 \mathrm{~nm}$ to $10 \mu \mathrm{m}$. ELPI device is well described in Marjamäki et al. [39]. Particle number and concentrations calculated accounts for $1 \mathrm{~g} \cdot \mathrm{cm}^{-3}$ of density value. In a dense medium in drops, it was shown by multidimensional numerical calculations that the collection of the aerosols of the inertial field could be modified. The presence of several drops modifies the flow inducing a reduction in the effectiveness of collection and the presence of a layer of incondensable gases around a drop generates an increase in the deposit of the aerosols on these drops on the higher plates of the impactor ranged from 3 to $10 \mu \mathrm{m}$ by diffusiophoresis and thermophoresis [[40], [41], [42]]. For these reasons, if particle matter was collected on the twelve plates of the ELPI from $7 \mathrm{~nm}$ to $10 \mu \mathrm{m}$, number size distributions were 
only calculated for PM2.5 in this study and do not take into account impaction stages 10 to 12 . Only stages 1 to 9 were considered and represent PM2.5. A Fine Particle Sampler (FPS-4000 model) manufactured by DEKATI was used to dilute wood fume before ELPI analyzes. Sampling between the chimney and the FPS was realized by the use of a heated line maintained at $120^{\circ} \mathrm{C}$. The total mass fraction of Total Suspended Particles has been measured by gravimetry according to DIN Certco certification rules [30]. Three experiments were done for each type of wood pellets and the mean was calculated and given in the section 3 below. Particles emitted during the tests were also collected with a sampling device (CATECO model) provided by CleanAir EUROPE allowing sampling in isokinetic conditions. The system consists of a heated sampling probe connected to a heated filter holder in which glass fiber filter is placed to collect particles. This system was maintained at a temperature of $120^{\circ} \mathrm{C}$. A refrigerated collecting system follows the filter to condense water vapor and collect gaseous volatile organic compounds on a resin trap. The whole system is connected to the sampling pump and the flow control device. A half of each filter and the XAD-2 resin (Restek - Ultraclean Resin) collected were submitted to a soxhlet extraction by dichloromethane/acetone (50/50) during $24 \mathrm{~h}$. Condensates were treated by liquid/liquid extraction with dichloromethane only. These extracts were dedicated to the solid, gaseous and condensable (liquid as tars) PAH and phenolic compounds analysis. The other half of the filter was used to quantify the organic biomass combustion tracers (e.g. levoglucosan, mannosan, galactosan). It was sonicated in ethyl acetate during $1 \mathrm{~h}$ and then derivatized. The extracts obtained were concentrated under nitrogen flux and analyzed by GC/MS (VARIAN 3800/1200 TQ).

COV as BTEXT are trapped on TENAX cartridge, and aldehydes/ketones on DNPH cartridge connected to a sampling pump equipped with flow control device. TENAX cartridges are then thermally desorbed with a thermodesorber (Perkin Elmer TurboMatrix TD) equipped with a cold trap before being analyzed by GC/MS (PerkinElmer Clarus 680). DNPH cartridges are eluted with acetonitrile and then analyzed by HPLC coupled with a Photo Diode Array detector (Waters Alliance 2695/PDA 996).

\section{Results and discussion}

\subsection{Effect of washing pre-treatment on standardized pollutants}

Fig. 3 presents the influence of the washing pre-treatment on $\mathrm{CO}$ concentrations and its comparison with French and European standards. Concentrations of $\mathrm{CO}$ are relatively high for raw biomasses except for DIN+ Certco pellets which are standard solid fuel used for standardized combustion tests on small domestic pellet stoves. The tests carried out with pellets of raw fir, beech and oak wood lead to concentration of CO Two to three times higher than DIN+ pellets results. Comparison of the real time concentrations of $\mathrm{CO}$ for both soft (DIN+) and hard (oak) wood pellets is given in the Supplementary Material. Concentrations of $\mathrm{CO}$ measured during the combustion of non-standardized wood as leafy species (oak and beech) are higher throughout the process than those of coniferous mixture (DIN+) and/or raw fir pellets. The Table 4 details the influence of the washing process on emission factors of both gaseous and particulate pollutants. Mean values of CO for DIN+ and fir pellets are 193 and $330 \mathrm{mg} \cdot \mathrm{MJ}^{-1}$ corresponding to high loads. Compared to mean values (95-150 mg. $\mathrm{MJ}^{-1}$ ) obtained by Boman et al. with a standard American pellets stove registered for high load of 5-6 kW with fir and spruce pellets, our emission factor values are in the range but remain quite high [7]. Ozgen and al. obtained very low emission factor of $88 \mathrm{mg} \cdot \mathrm{MJ}^{-1}$ after $1 \mathrm{~h}$ at nominal output with an automatic $8 \mathrm{~kW}$ pellet stove representing the Italian market [3]. 


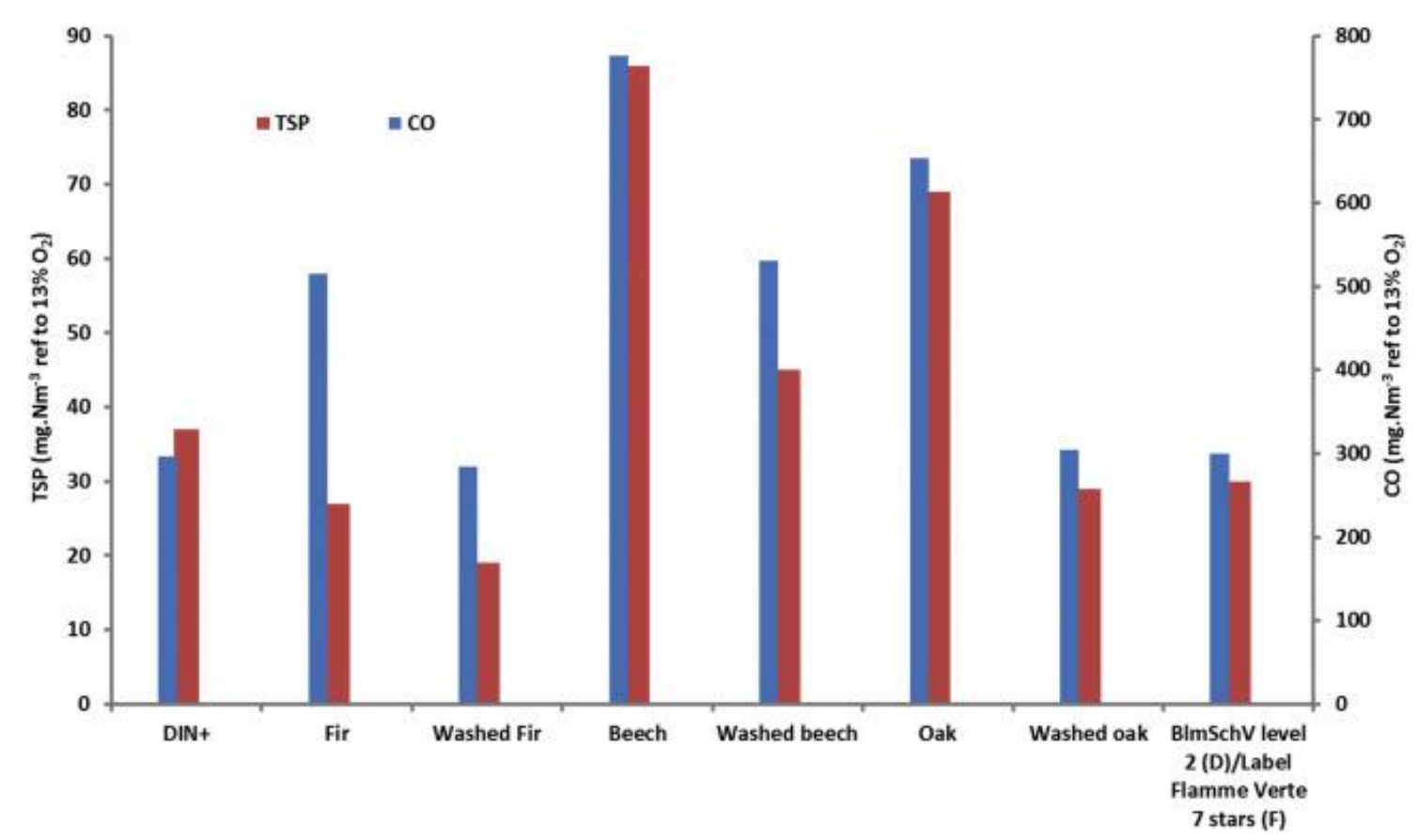

Fig. 3. Influence of the washing pre-treatment on gaseous and particulate pollutant concentrations and their comparison with French and European standards.

Table 4. Emission factors of gaseous and particulate pollutants.

\begin{tabular}{|c|c|c|c|c|c|c|c|}
\hline$\left(\mathrm{mg} \cdot \mathrm{MJ}^{-1}\right)$ & DIN+ & Fir & Washed fir & Beech & Washed beech & Oak & Washed oak \\
\hline $\mathrm{CO}$ & $193 \pm 12$ & $330 \pm 15$ & $225 \pm 22$ & $520 \pm 16$ & $396 \pm 22$ & $461 \pm 18$ & $239 \pm 17$ \\
\hline NOx & $80 \pm 20$ & $73 \pm 25$ & $70 \pm 34$ & $130 \pm 26$ & $120 \pm 35$ & $147 \pm 30$ & $136 \pm 28$ \\
\hline TSP $^{a}$ & $23 \pm 3$ & $17 \pm 2$ & $14 \pm 2$ & $57 \pm 8$ & $34 \pm 3$ & $49 \pm 1$ & $23 \pm 1$ \\
\hline $\begin{array}{l}\text { NMVOC } \\
\text { (eq. } \mathrm{CH}_{4} \text { ) }\end{array}$ & $<\mathrm{LOQ}^{\mathrm{b}}$ & $13 \pm 7$ & $<L O Q$ & $<L O Q$ & $<\angle O Q$ & $<L O Q$ & $<\mathrm{LOQ}$ \\
\hline $\begin{array}{l}\text { VOC } \\
\text { (eq. } \mathrm{CH}_{4} \text { ) }\end{array}$ & $<\angle O Q$ & $14 \pm 7$ & $<\angle O Q$ & $<\angle O Q$ & $<\angle O Q$ & $<\angle O Q$ & $<\angle O Q$ \\
\hline
\end{tabular}

a Three TSP measurements.

b LOQ was determined and is equal to $8 \mathrm{mg} \cdot \mathrm{MJ}^{-1}$.

As previously shown by Schmidl et al., nature of the pellets (conventional soft wood pellets, triticale, Miscanthus) could highly influence the emissions of pollutants for a same combustion phase (as started-up phase, partial or load phases) [8]. Products of incomplete combustion (PIC) as CO and PAH also strongly depend on air staging facilities (primary or/and secondary) with large impacts on air ratios. In our pellet stove as in most domestic pellets stoves and boilers, combustion proceeds with high air ratios between 4 and 7 [7].

Air ratios for raw fir, beech and oak pellets are similar to this for DIN+ being in the same order of magnitude. This stove is especially designed to produce heat at low output power according to new standard building data [43] using as fuel reference DIN+ pellets. Air ratio was optimized for combustion of DIN+ pellets. For raw pellets, the increase of CO concentrations could not be attributed to a modification of the air ratio. The behavior of these non-conventional pellets, especially for hard woods as beech and oak, could be different during combustion leading to higher concentrations of PIC. 
Even if the $\mathrm{CO}$ concentrations measured are quite high by comparison with referred DIN+ pellets, the washing process leads to a decrease of this pollutant in the exhaust ranging between 31 and $51 \%$ for all type of pellets (i.e. Table 4). This result is similar to that of Ravichandran and Corscadden who burnt in a domestic wood stove unleached and leached agricultural biomass briquettes [44]. They also observed $\mathrm{CO}$ emissions reduced by $50 \%$. As shown in the Table 3, the air ratios increase for washed samples compared to raw pellets except for washed oak. This increase of the air ratio could not explain the reduction of PIC as CO and PAH (see below in part 3.2.4). Leaching of wood species eliminate soluble organic and mineral forms of carbon (mainly wood extractives as shown in Table 1). The reduction of PIC could be related to a loss of the total carbon initially contained in the raw wood species. Another hypothesis to explain the decrease of $\mathrm{CO}$ emissions could be pointed out with regards to Nishimura et al. results. Nishimura et al. have investigated the role of the potassium carbonate on the cellulose pyrolysis mechanism [45]. The presence of potassium largely favors the gasification of cellulose with an increase of gaseous species as $\mathrm{H}_{2}, \mathrm{CO}$ and $\mathrm{CO}_{2}$. The ring-opening of _ bonds of cellulose were accelerated by the addition of $\mathrm{K}_{2} \mathrm{CO}_{3}$ with the emission of light hydrocarbon molecules. The reduction of potassium from biomass samples by the leaching process could disfavor the pyrolysis mechanism of saccharide polymers during the starting phases of the thermal treatment leading to lower CO concentrations in the exhaust.

Regarding to the standard deviation, emission factors for NOx are in the same order of magnitude for $\mathrm{DIN}+$ and fir pellets than this obtained by Ozgen during the combustion of DIN+ pellets in a stove of $8 \mathrm{~kW}$ representing the recent Italian market with an average value of $60 \mathrm{mg} \cdot \mathrm{MJ}^{-1}$ at nominal output for $1 \mathrm{~h}$. Pellets manufactured from hard woods (beech and oak) present emission factors two times higher than for soft wood pellets [3]. The main origin of NOx in solid biomass combustion is generally attributed to the amount of elemental nitrogen in the fuel and then fuel NO. The standard resolution of nitrogen determination during elemental analysis (Table 1 ) is not sufficiently precise to show differences for fuels with low nitrogen content. As shown in Table 4 and regarding to standard deviations, the washing procedure does not affect the emissions of NOx in the exhaust.

In Table 4, emission values for TSP ranging from 14 to $57 \mathrm{mg} \cdot \mathrm{MJ}^{-1}$ are quite low compare to those given in the literature [46]. Comparisons need to be careful because values strongly depend on the sampling methodology (sampling temperature, nature of the filter, trapping in impingers, nature of the solvents, etc.) as it was well explained by Nussbaumer [46]. Our values are in the same order of magnitude than those reported by Nussbaumer for combustion experiments in domestic pellet stoves representing the European market using woods with low bark fraction to manufacture pellets with low ash content [46]. Ozgen obtained an average value of $109 \mathrm{mg} \cdot \mathrm{MJ}^{-1}$ at nominal output during the combustion of DIN+ pellets in a stove of $8 \mathrm{~kW}$. According to the Norwegian standard, the gas temperature at the quartz filter holder was between 32 and $35^{\circ} \mathrm{C}$ [47]. This low temperature allows the condensation of semivolatile compounds present in the gas phase and could overestimate emission factors compared to the DIN Certco regulation rules [30]. Applying this regulation, the filter holder in our experiments was maintained at a temperature ranging from $80^{\circ} \mathrm{C}$ to $110^{\circ} \mathrm{C}$ in order to minimize the condensation of organic and mineral semi-volatile compounds. This difference of temperature explains the higher value obtained by Ozgen in comparison with values measured in this study because semi-volatile compounds are not condensed in our case, the temperature of the sampling probe being much more higher than this used by Ozgen [3].

The effect of the washing procedure is also pointed out for the values of TSP emission factors with a main decrease for beech and oak pellets, regarding to the relative standard deviations in the range of 5-13\% depending of the samples. Generally, biomasses pretreatment leads to two times less TSP emissions during combustion as shown in Table 4. Ravichandran and Corscadden also observed a more significant effect of the leaching of agricultural biomass briquettes during their combustion in a domestic stove. Indeed, the emissions of TSP decreased close to $40 \%-50 \%$, depending of the agricultural specie (Switch, Wheat, Reed and Barley) [44]. While the observed trend is quite similar 
with this study, their emission values for TSP are higher than these of this study for both unleached and leached samples. This difference could be explained by the difference of the combustion devices. The quasi steady state combustion of pellet stoves is known to reduce TSP emissions in comparison to other wood burning devices.

\subsection{Effect of washing pre-treatment on chemical speciation of organic compounds}

The speciation of organic molecules in gaseous, liquid and solid phases was performed only one time and the following results are trends.

\subsubsection{Repartition of VOC and case of BTEXT}

As given in Table 4, total VOC were detected only for raw fir pellets. NMVOC largely dominate in the flue gas compared to Methanic Volatile Organic Compounds (MVOC) with proportion values ranging from 90 to $100 \%$ of the TVOC. Regarding to the standard deviation, the mean emission factor is very close to this obtained by Ozgen for and pellet stove of $8 \mathrm{~kW}$ with an average value of $9 \mathrm{mg} \cdot \mathrm{MJ}^{-1}$. Boman also got TVOC ranging from 1.1 to $42 \mathrm{mg} \cdot \mathrm{MJ}^{-1}$ for two domestic pellet stoves (a modern Scandinavian stove with air staged combustion applied and a classic North American). Boman got the lowest values at full loads for the modern one and the highest ones for both stoves working at low load. The mixing of air and combustible gases due to lower velocities could explain the highest values $[7,48]$. For all of cases, concentrations of MVOC were under the limit of quantification. The influence of the pretreatment on total concentrations could not be analyzed for this reason.

BTEXT molecules were analyzed in the gas phase as shown in the Fig. 5. The major compounds are, in increasing order, toluene, benzene and trimethylbenzene which represent 88 to $96 \%$ of the six molecules detected for all three. Trimethylbenzene is the major molecule measured with a proportion between 42 and $69 \%$. Concerning benzene and toluene, their concentrations ranged respectively between 15 and $37 \%$ for the first, and between 5 and $14 \%$ for the second.

About the effect of washing biomass, the observations are not significant for all biomasses as shown in the Fig. 4. Indeed, a decrease of $59 \%$ is observed in the case of washed oak combustion but an increase of $250 \%$ is recorded for washed fir. Combustion of washed beech wood seems to be equivalent to raw beech in terms of BTEXT emissions. Variations observed on total BTEXT emissions are mainly due to trimethylbenzene evolution. Thereby, for raw biomasses combustion, values for fir, oak and beech wood are respectively 692, 1506 and $1952 \mu \mathrm{g} \cdot \mathrm{kg}^{-1} \mathrm{dw}$. These factors are lower than the one determined by Boman et al. [7] for softwood combustion which are close to $5400 \mu \mathrm{g} \cdot \mathrm{kg}^{-1} \mathrm{dw}$, even if trimethylbenzene was not quantified in this study. This can probably be explained by the difference of generation, i.e. the difference of performance of the stoves used. Environmental performances of wood pretreatment on BTEXT emissions are strongly influenced by the variety of wood studied $[6,7]$. 


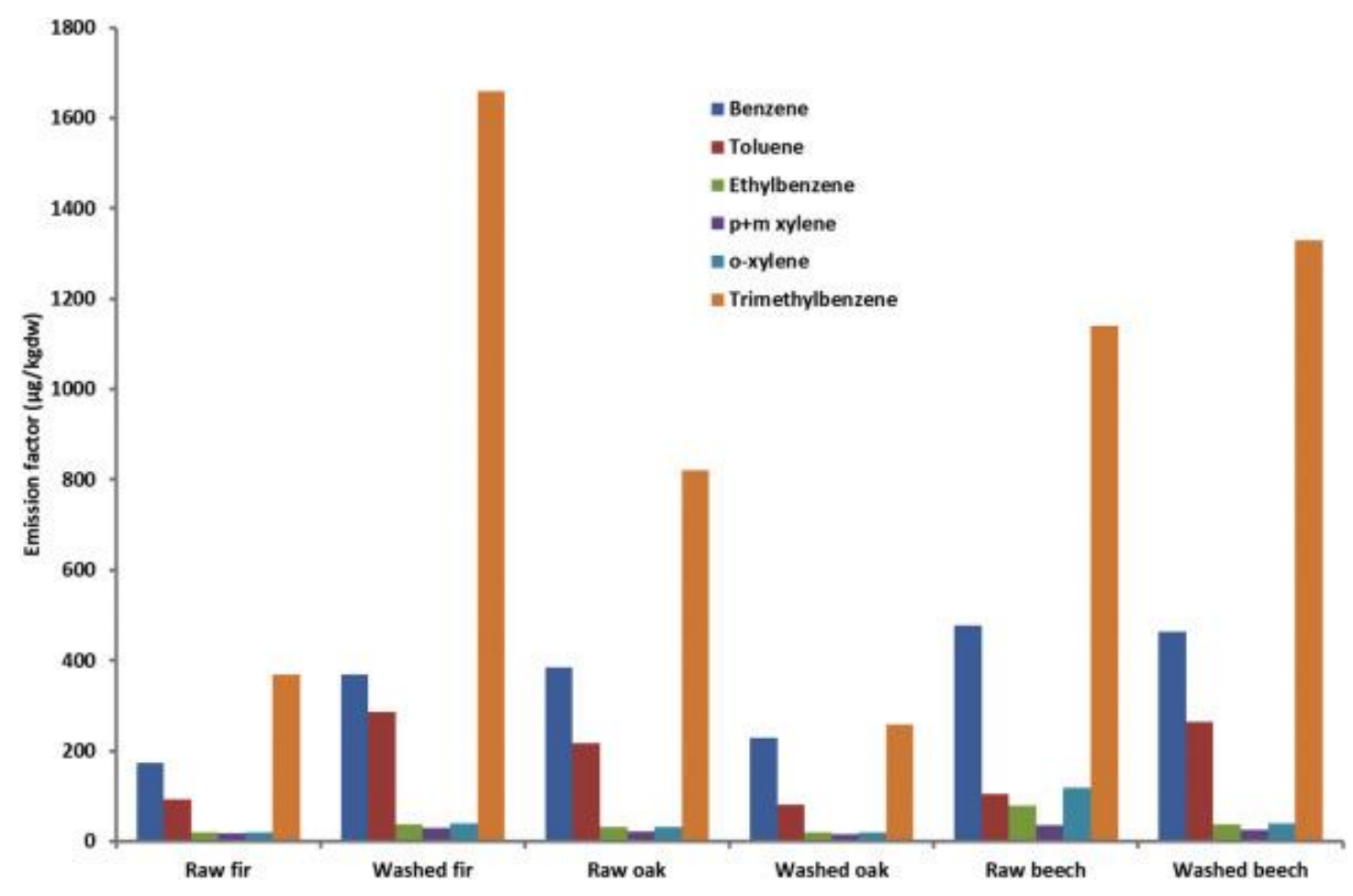

Fig. 4. Evolution of the BTEXT emission factors with the pre-treatment.

\subsubsection{Case of phenols}

In the case of biomass combustion, phenolic compounds come from the thermal degradation of lignin [49]. In this study, three phenols have been analyzed in gaseous, liquid and solid phases: phenol, guaiacol and syringol. Syringol was not detected in none of all samples. Guaiacol only represents a maximum of $3 \%$ of the total of the three phenols, the main compound detected being the phenol with 97 to $100 \%$ of total phenolic emissions mainly found in the liquid phase with emission factors values of 200,330 and $900 \mu \mathrm{g} \cdot \mathrm{kg}^{-1} \mathrm{dw}$ for raw oak, beech and fir respectively. Phenol distribution in the three phases for all biomasses is represented in Fig. 5 . These phenols emissions values are consistent with the study of Tschamber et al. [50] concerning emissions of charm logs in a wood log stove. Indeed, only phenol molecule was detected with values ranged between 250 and $750 \mu \mathrm{g} \cdot \mathrm{kg}^{-1} \mathrm{dw}$. Thus, the following comments on the effect of washing only focus on phenol values.

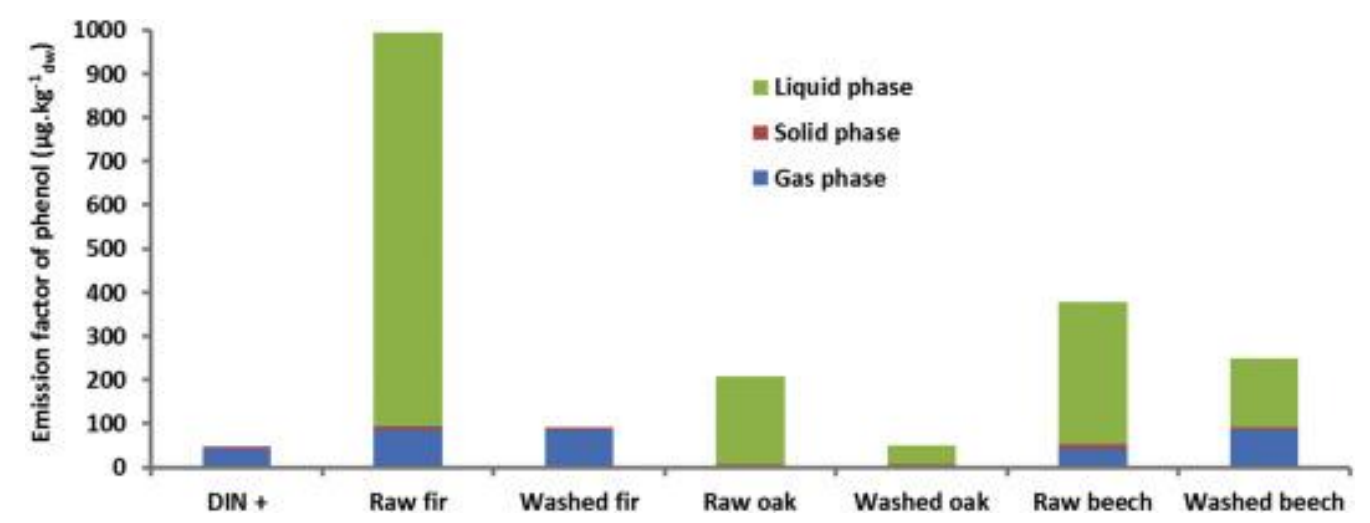

Fig. 5. Repartition of phenol molecule in the gas, particulate and condensed phase. 
Washing of biomass shows a benefic impact on phenol emissions in comparison with raw biomass burning. In fact, total phenol emissions which are the sum of liquid, gas and solid phase emissions, can be reduced respectively by $91 \%, 76 \%$ and $34 \%$ for washed fir, oak and beech. After the washing process, the molecule of phenol is also mainly found in the liquid phase for oak and beech with values of 44 and $158 \mu \mathrm{g} \cdot \mathrm{kg}^{-1} \mathrm{dw}$. In the case of fir pellets this molecule is mainly found in the gas phase with a value of $87 \mu \mathrm{g} \cdot \mathrm{kg}^{-1} \mathrm{dw}$. Total phenol emission is twice higher for washed fir than for DIN + pellets combustion, the two biomasses show a similar repartition with approximately $90 \%$ of phenol in gas phase and $10 \%$ in liquid phase.

These combustion results are in agreement with the pyrolysis-GC/MS study on demineralization of lignocellulosic biomass led by Eom et al. [28]. According to Eom et al. [28], the decrease in phenol emission after biomass demineralization could be explained by the catalytic role of inorganics on the cleavage of carbon-carbon linkage during the pyrolysis of lignin polymer. In a more recent article, Eom et al. demonstrated that an increase in potassium content of poplar wood enhanced the formation of phenol compounds by acting as catalyst in the demethoxylation of guaiacyl units during the pyrolysis of lignin polymer [51]. The molecules of phenol, guaiacol and syringol were the most impacted.

Furthermore, fir and oak bark are rich in phenolic matter [52]. This could also explain that a higher decrease of phenol emissions is observed for the combustion of these two washed species. Indeed, thanks to the solubility of phenolic compounds in water, they could have been extracted during the washing process. This hypothesis is strength by results of the biochemical composition shown in Table 1. Wood extractives cover various compounds in wood other than the major wood constituents such as cellulose, hemicellulose and lignin, which include fatty acids, lipids, terpenoids, phenolic compounds and glycosides mostly soluble in water [53]. The leaching process mainly affects the reduction of extractives ratio for fir and oak, respectively. As it is shown in Table 1, extractives from oak are particularly affected by the leaching process with a decrease close to $60 \%$. This result could be explained by the high level of tannins contained in hard wood specie as oak [54]. Similar trends are found for both TOC and extractives values during the leaching process even if the TOC in residual solutions were very low. $24 \mathrm{~h}$ of leaching seems to be not sufficient to extract the total TOC part contained in woods. During the pyrolysis decomposition phase of the biomass, less of these molecules are devolatilized leading to lower emission factors.

\subsubsection{Case of aldehydes and ketones}

Ten aldehydes from carbon number C1 (Formaldehyde) to C8 ( $p$-tolualdehyde) and two ketones (acetone and butanone) were analyzed in the gas phase as shown in the Table 5. Main aldehydes detected are acetaldehyde and propionaldehyde which both represent 28 to $63 \%$ of the total of the 12 compounds quantified for all biomasses (raw and washed). Valeraldehyde accounts for a quarter of raw beech aldehydes emissions. In terms of total aldehydes emissions, combustion of washed woods shows an increase by $33 \%$ and $60 \%$ for fir and oak respectively, contrary to washed beech emissions which decrease by $9 \%$. It is important to notice that DIN+ pellets emissions are significantly lower than all biomasses burnt by a factor 2.5 to 8.6. Indeed, concerning raw biomasses, emission factors of total aldehydes and ketones for DIN+, fir, oak and beech pellets are respectively 1382, 4524, 3412 and $11,862 \mu \mathrm{g} \cdot \mathrm{kg}^{-1} \mathrm{dw}$. For washed biomasses, emission factors values for fir, oak and beech pellets combustion are respectively 6029,5448 and $10,818 \mu \mathrm{g} \cdot \mathrm{kg}^{-1} \mathrm{dw}$. 
Table 5. Influence of the washing pre-treatment on emission factors of aldehydes and ketones.

$\begin{array}{llllllll}\begin{array}{l}\text { Compounds/woods } \\ \left(\mu \mathrm{g} \cdot \mathbf{k g}^{-1} \mathrm{dw}\right)\end{array} & \text { DIN } & \text { Fir } & & \text { Beech } & \text { Oak } \\ \text { Formaldehyde } & \text { Certco } & \text { Raw } & \text { Washed } & \text { Raw } & \text { Washed } & \text { Raw } & \text { Washed } \\ \text { Acetaldehyde } & 295 & 273 & 536 & 1312 & 1829 & 729 & 1140 \\ \text { Acroleine+acetone } & 271 & 1868 & 2341 & 3767 & 3116 & 1475 & 1317 \\ \text { Propionaldehyde } & 157 & 695 & 501 & 616 & 0 & 398 & 535 \\ \text { Crotonaldehyde } & 119 & 722 & 1000 & 1830 & 848 & 660 & 636 \\ \text { Methacroleine }+ \text { butanone } & 36 & 299 & 154 & 0 & 0 & 0 & 317 \\ \text { Benzaldehyde } & 0 & 0 & 0 & 630 & 3306 & 73 & 65 \\ \text { Valeraldehyde } & 147 & 190 & 457 & 413 & 618 & 77 & 192 \\ \text { p-Tolualdehyde } & 56 & 477 & 482 & 3080 & 80 & 0 & 0 \\ \text { Hexaldehyde } & 233 & 0 & 395 & 132 & 849 & 0 & 1013 \\ \text { Total } & 70 & 0 & 162 & 83 & 172 & 0 & 233\end{array}$

\subsubsection{Case of PAH}

According to the US-EPA, 16 PAH were measured. Fig. 6a shows the PAH profiles determined during the combustion tests of the seven studied biomasses. Detailed emission factors are given in the Table 6. Every wood species present more or less similar PAH profiles except for raw fir mainly due to high concentrations of naphthalene and acenaphthylene. Moreover, raw fir emissions are not in the same range than other wood varieties. DIN+ pellets are mainly constituted of softwood as fir and their own PAH emissions values are higher than hardwood as beech and oak. Excepted for the 3 lighter PAH, $\mathrm{DIN}+$ and raw fir pellets show similar profiles of PAH emissions and the same range of concentrations. $\mathrm{DIN}+$ emissions are about $870 \mu \mathrm{g} \cdot \mathrm{kg}^{-1} \mathrm{dw}$ and other biomasses emissions are close to $400-600 \mu \mathrm{g} \cdot \mathrm{kg}^{-1} \mathrm{dw}$, raw fir emissions are much higher with $1570 \mu \mathrm{g} \cdot \mathrm{kg}^{-1} \mathrm{dw}$. Softwood combustion is well-known for a long time and numerous literature data are available to explain that it largely contributes to give tars and to soot contrary to hardwood. CO and PAH are PIC and PAH are defined as soot precursors [55]. It explains the fact that DIN+ pellets and raw fir pellets show the highest values. The PAH concentrations measured in this study are in accordance with the study of Boman et al. [7] with values ranging between 135 and $4040 \mu \mathrm{g} \cdot \mathrm{kg}^{-1} \mathrm{dw}$. One point advanced by Boman to explain the high range of magnitude is related to the age of the combustion device. PAH emissions recorded on a recent pellet stove are largely lower than an old wood stove. As example, Mac Donald et al. has studied hardwood combustion in an old wood stove that exhibited emission factors close to $75 \mathrm{mg} \cdot \mathrm{kg}^{-1} \mathrm{dw}$ while in our

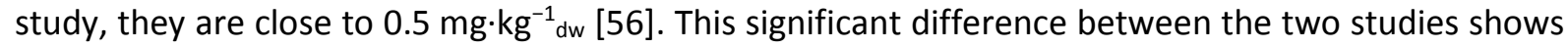
the progress realized in terms of optimization of the performance of wood heating device. 


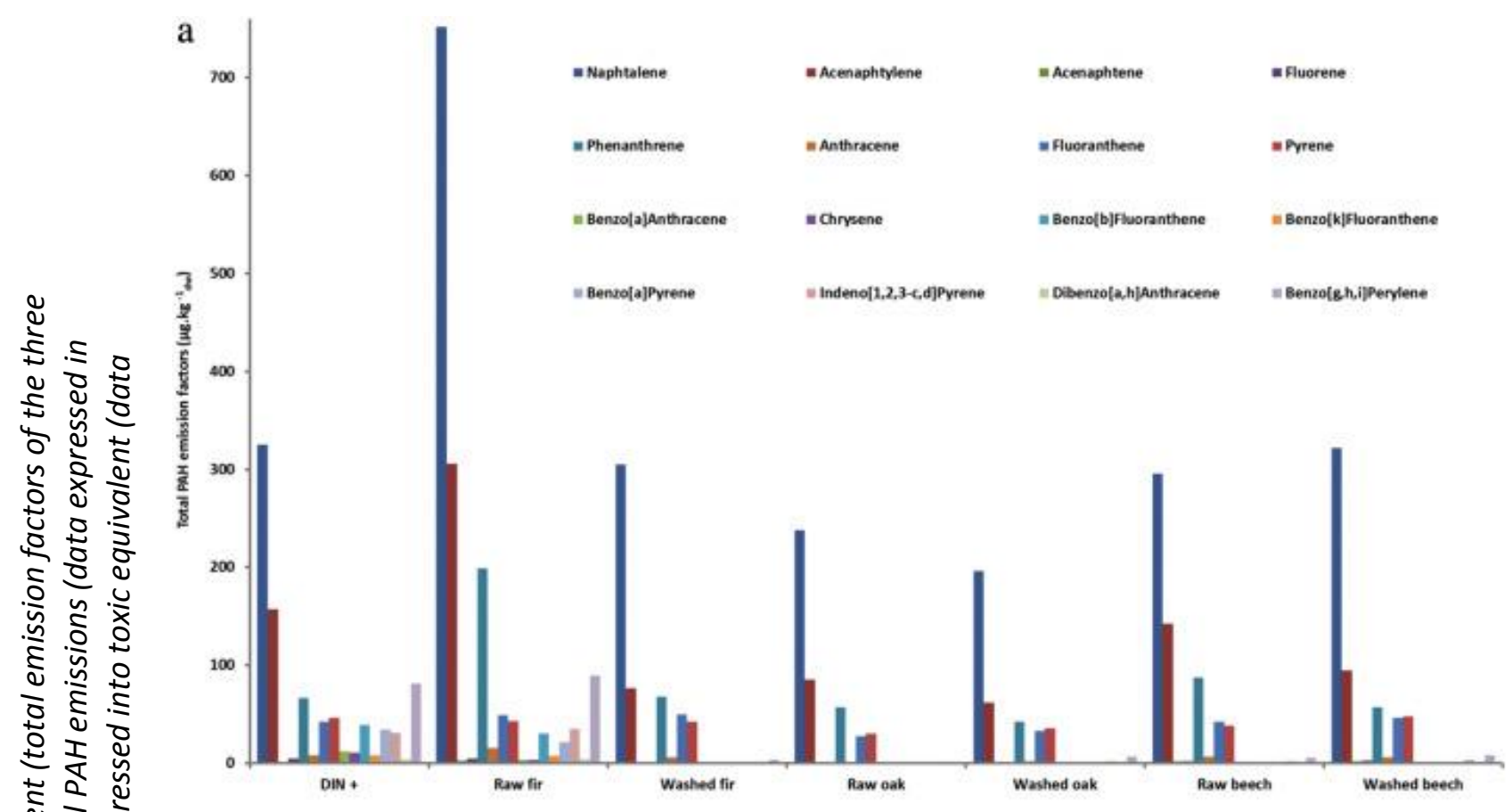

b

\&

¿े 气 जิ

스를

ป

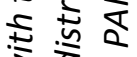

3 ป

ป 눈

ड

잉

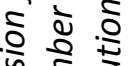

जิ

के $\frac{1}{2}$

$x \geqslant \frac{2}{2}$

¿

ว

ミ

으 ह

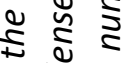

पू है

โ

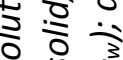

$\underbrace{2}{ }^{3}$

은

ம

i⿱宀⿻⺀大
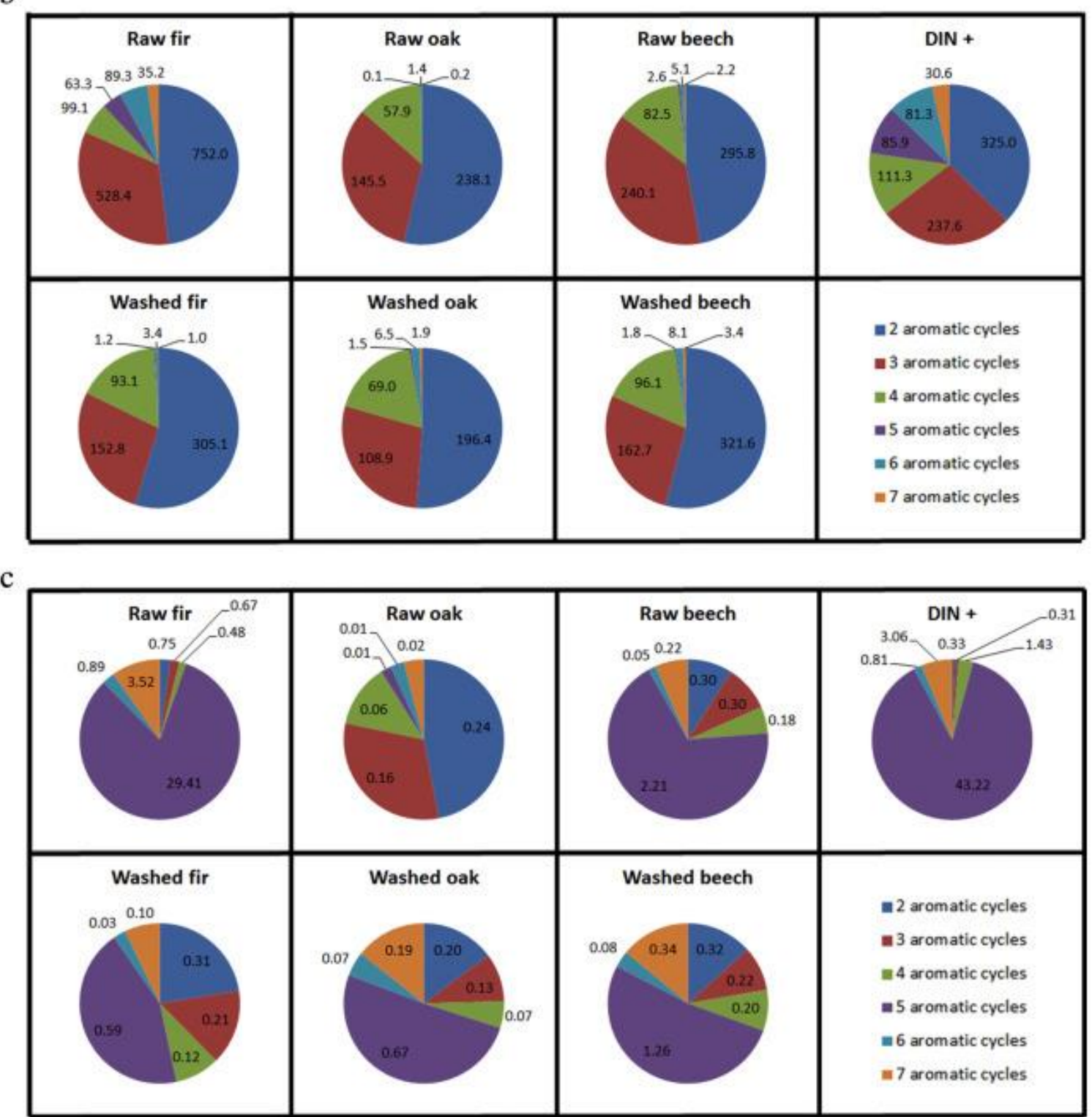
Table 6. Influence of the washing pre-treatment on total emission factors of PAH.

\begin{tabular}{|c|c|c|c|c|c|c|c|}
\hline \multirow{2}{*}{ Emission factors of PAH } & \multirow{2}{*}{ DIN+ } & \multicolumn{2}{|l|}{ Fir } & \multicolumn{2}{|c|}{ Beech } & \multicolumn{2}{|l|}{ Oak } \\
\hline & & Raw & Washed & Raw & Washed & Raw & Washed \\
\hline $\begin{array}{l}\text { Total } \\
\left(\mu \mathrm{g} \cdot \mathrm{kg}_{\mathrm{dw}}{ }^{-1}\right)\end{array}$ & 870 & 1570 & 560 & 630 & 590 & 440 & 380 \\
\hline $\begin{array}{l}\text { Evolution } \\
\text { (\%) }\end{array}$ & - & -64 & & -6 & & -14 & \\
\hline $\begin{array}{l}\text { Total } \\
(\text { eq. BaP) } \\
\left(\mu \mathrm{g} \cdot \mathrm{kg}_{\mathrm{dw}}{ }^{-1}\right)\end{array}$ & 49.2 & 35.7 & 1.4 & 3.3 & 2.4 & 0.5 & 1.3 \\
\hline $\begin{array}{l}\text { Evolution } \\
\text { (\%) }\end{array}$ & - & -96 & & -27 & & +163 & \\
\hline
\end{tabular}

a Emissions were corrected by the toxic equivalent factor for individual PAH [42].

Fig. 7 shows the repartition of total PAH in the different phases. These molecules are mainly present in the gas and liquid phases. But proportions in the gas phase dominate with values ranging from 82 to $94 \%$ for raw and washed pellets. Soft wood pellets slightly differ with a small part of total PAH (15 to $25 \%$ ) in the solid phase related to a sooting behavior. Light PAH ( 2 to 3 aromatic rings) were mainly found in the gas phase while heavy PAH (a minimum of 5 aromatic rings) were present in solid phase and 4 aromatic rings PAH were mostly in liquid phase. The washing process does not significantly influence the repartition of total PAH in the different phases excepted for fir pellets where the part of solid PAH is strongly reduced (from 12 to $1 \%$ ).

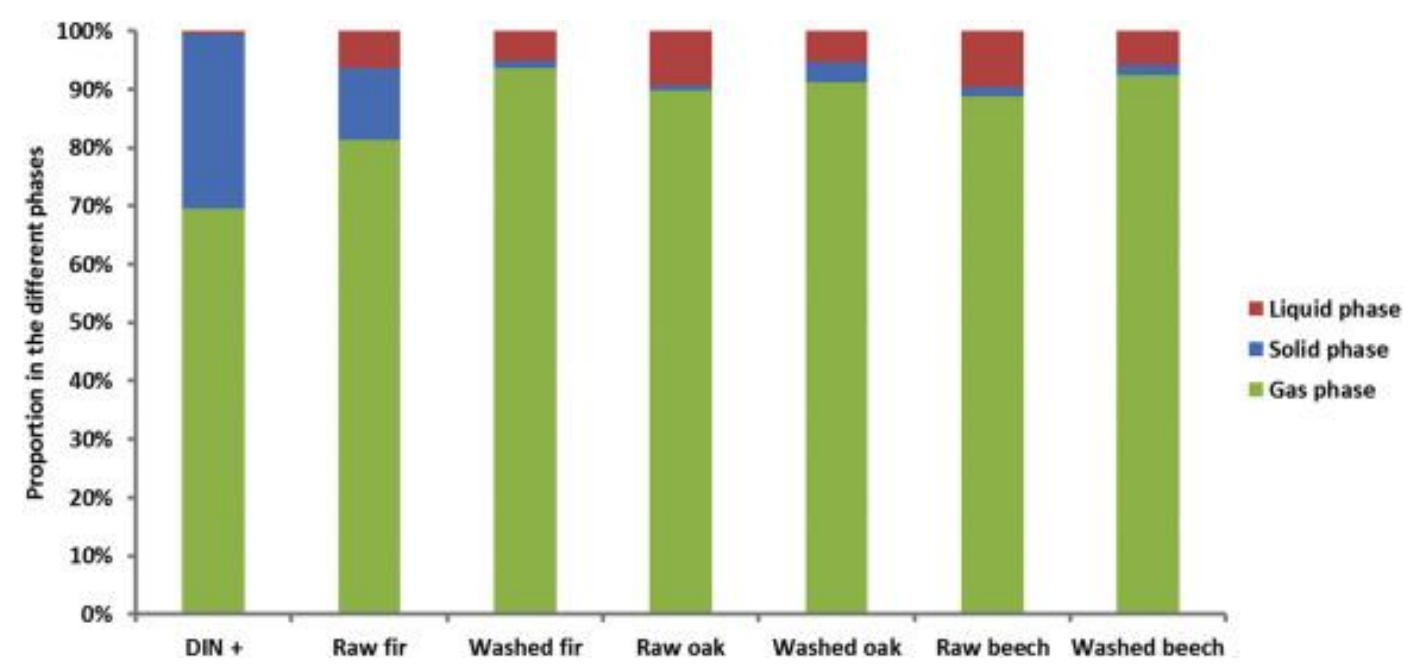

Fig. 7. Relative distribution of total PAH in the different phases.

In order to estimate the toxicity of PAH emissions, the French agency INERIS has published factors (toxic equivalent factor) for each of the $16 \mathrm{PAH}$ to convert emission values into toxics emissions values [57]. These factors are expressed in equivalent Benzo[a]Pyrene which is the more toxic of the $16 \mathrm{PAH}$ because of its carcinogenic properties for human. Emission factors have been converted using TEF and results are presented in Table 6. DIN+ pellets show higher values than other biomasses with respectively $49.2 \mu \mathrm{g}$ (Eq. BaP) $\cdot \mathrm{kg}^{-1} \mathrm{dw}$. Washing pre-treatment on beech and oak emissions has not significant effect with values ranging from 0.5 to $3.3 \mu \mathrm{g}\left(\mathrm{Eq}\right.$. BaP) $\cdot \mathrm{kg}^{-1} \mathrm{dw}$. Concerning fir emissions, 
toxicity is reduced by $96 \%$ using washed fir. Indeed, washing of fir decreases significantly PAH emissions switching from 35.7 to $1.4 \mu \mathrm{g}$ (Eq. BaP) $\cdot \mathrm{kg}^{-1} \mathrm{dw}$. Wood pre-treatment does not significantly affect beech and oak emissions contrary to fir PAH emissions which can be reduced by $64 \%$. In general, washing biomass does not influence PAH repartition between the three phases and main PAH detected are the same for raw and washed wood combustion. Only the concentration of some compounds can be influenced by the washing process.

In terms of the number of cycle distribution for PAH calculated from total emission factors, Fig. $6 \mathrm{~b}$ shows that whatever the species and regardless if the wood is washed or not, the repartition is substantially the same. Only raw softwoods slightly differ with a higher proportion of PAH containing 5 to 7 aromatic rings. Fig. $6 \mathrm{c}$ represents the number of cycle distribution for PAH expressed into international toxic equivalent. Considering low values for oak and beech, washing pretreatment does not modify repartition. DIN+ and raw fir repartition are quite similar. In the case of fir washing, the number of cycle distributions from toxic equivalent factor emissions is really influenced: distribution of 5 cycles PAH is reduced by a factor 2 to the benefit of 2 to 4 cycles PAH which are less toxic as shown in Fig. 6c.

As shown in Table 1, the extractive part of the wood is affected by the leaching process. A lot of ethylenic and aromatic molecules present in the composition of the extractives in wood as terpenoids and phenolic compounds [58] are reduced by dissolution in water. The reduction of these molecules acting as precursors of PAH could favor the decrease of PAH emission factors, accordingly. Another explanation could be pointed out according to Nishimura et al. results [45]. Nishimura et al. demonstrated the role of the potassium in the gasification of the cellulose with the increase of yields of gases $\left(\mathrm{H}_{2}, \mathrm{CO}\right.$, light VOC) and low molecular weight PAHs, such as naphthalene and anthracene in the range of temperatures studied (up to $1000^{\circ} \mathrm{C}$ ). Moreover they demonstrated that the yields of other PAHs like Benzo[a]Pyrene increased for temperatures up to $600^{\circ} \mathrm{C}$. As for $\mathrm{CO}$ (see Section 3.1), the reduction of potassium from biomass samples by the leaching process could disfavor the pyrolysis mechanism of saccharide polymers during the starting phases of the thermal treatment leading to less $\mathrm{PIC}$ as $\mathrm{CO}$ and PAHs.

\subsection{Effect of washing pre-treatment on size distributions of PM2.5}

Mean total number concentrations and emission factors in $\mathrm{PM}_{2.5}$ are given in Table 7. The values are expressed in different units in order to get sufficient comparisons with literature data. Results are equivalent (same orders of magnitude) to previous data obtained thanks to ELPI measurements for similar small output pellet stoves and boilers [[59], [60], [61], [62], [63]]. In the Fig. 8 are also given the number size distributions related to three size fractions in the $\mathrm{PM}_{2.5} . \mathrm{PM}_{2.5}$ are mainly constituted of $\mathrm{PM}_{1}$ for all raw and washed samples, representing $99.9 \%$ of the total number of particles. There is a significant difference between the two fractions $\mathrm{PM}_{0.1}$ and $\mathrm{PM}_{0.1-1}$. A similar distribution was previously observed by Sippula et al. during combustion of pellets from different woods and agricultural residues in a commercial top-feed Wodtke $\mathrm{GmBH}$ stove working at nominal output of $8 \mathrm{~kW}$ [63]. In Sippula's results, $\mathrm{PM}_{1}$ largely dominated in number with emission factors close to 5.1 to $5.910^{13} 1 \cdot \mathrm{MJ}^{-1}$ for birch, fir and spruce stems. The presence of bark during the manufacturing of pellets allows an increase of fine particles in the exhaust ranging from $1.410^{13} 1 \cdot \mathrm{MJ}^{-1}$ to $7.110^{13} 1 \cdot \mathrm{MJ}^{-1}$ for willow barks and fir, respectively [63]. Regarding to standard deviations, raw fir, beech and oak pellets emitted much more $\mathrm{PM}_{2.5}$ than the DIN+ pellets in the exhaust. Because raw beech, raw fir and raw oak pellets contain higher ash contents than DIN+, this increase in $\mathrm{PM}_{2.5}$ concentrations and emissions factors could be attributed to a part of fine fly ash particles emitted during the combustion. As shown in the Table 1 , the washing process affects the ash content. The decreases by the dissolution of mineral matter contained in the wood species strength this result. Mass losses observed after the washing process were close to $38 \%, 32 \%$ and $25 \%$ for oak, beech and fir, respectively, oak specie being the most 
impacted by the washing procedure. The mass losses of minerals by dissolution during the process shown in Table 2 are in the same order of magnitude than ash losses for the three wood species with values equal to $17 \%, 22 \%$ and $34 \%$ for oak, fir and beech, respectively. Because ash contents are reduced, fly ashes should be less devolatilized in the exhaust. The washing process positively reduces by the same order of magnitude both ash content and emission factors of fine particles only for oak specie with a decrease of $\mathrm{PM}_{2.5}$ emission factors by a factor 1/3. The link between the loss of both ash content and particle emissions for beech and fir pellets is not significant, regarding to standard deviations.

Table 7. Influence of the washing pre-treatment on $\mathrm{PM}_{2.5}$.

\begin{tabular}{|c|c|c|c|c|c|c|c|}
\hline \multirow{2}{*}{ Np } & \multirow{2}{*}{ DIN + } & \multicolumn{2}{|l|}{ Fir } & \multicolumn{2}{|l|}{ Beech } & \multicolumn{2}{|l|}{ Oak } \\
\hline & & Raw & Washed & Raw & Washed & Raw & Washed \\
\hline $\begin{array}{l}\mathrm{PM}_{2.5} \\
\left(1 \cdot \mathrm{Ncm}^{-3}\right)^{\mathrm{a}}\end{array}$ & $5.6 \pm 0.1 \times 10^{7}$ & $7.3 \pm 1 \times 10^{7}$ & $6.5 \pm 0.1 \times 10^{7}$ & $7.7 \pm 0.2 \times 10^{7}$ & $7.2 \pm 0.2 \times 10^{7}$ & $8.1 \pm 0.2 \times 10^{7}$ & $5.4 \pm 0.1 \times 10^{7}$ \\
\hline $\begin{array}{l}\mathrm{PM}_{1-2.5} \\
(\%)\end{array}$ & 0.1 & 0.1 & 0.1 & 0.1 & 0.1 & 0.1 & 0.1 \\
\hline $\begin{array}{l}\mathrm{PM}_{0.1-1} \\
(\%)\end{array}$ & 76.0 & 56.3 & 29.5 & 83.7 & 62.2 & 83.6 & 68.5 \\
\hline $\begin{array}{l}\mathrm{PM}_{0.1} \\
(\%)\end{array}$ & 23.9 & 51.7 & 70.5 & 16.2 & 37.7 & 16.3 & 31.4 \\
\hline $\begin{array}{l}\mathrm{PM}_{2.5} \\
\left(1 \cdot \mathrm{kg}^{-1} \mathrm{dw}\right)\end{array}$ & $6.3 \pm 0.1 \times 10^{14}$ & $8.8 \pm 1 \times 10^{14}$ & $8.1 \pm 0.1 \times 10^{14}$ & $9.1 \pm 0.2 \times 10^{14}$ & $8.5 \pm 0.2 \times 10^{14}$ & $9.8 \pm 0.2 \times 10^{14}$ & $6.9 \pm 0.1 \times 10^{14}$ \\
\hline $\begin{array}{l}\mathrm{PM}_{2.5} \\
\left(1 \cdot \mathrm{MJ}^{-1}\right)\end{array}$ & $3.64 \pm 0.06 \times 10^{13}$ & $4.7 \pm 0.6 \times 10^{13}$ & $5.2 \pm 0.08 \times 10^{13}$ & $5.2 \pm 0.1 \times 10^{13}$ & $5.4 \pm 0.1 \times 10^{13}$ & $5.7 \pm 0.1 \times 10^{13}$ & $4.2 \pm 0.08 \times 10^{1}$ \\
\hline
\end{tabular}

a Volumes are expressed in STP and referred to $13 \% \mathrm{O}_{2}$ in the fume.

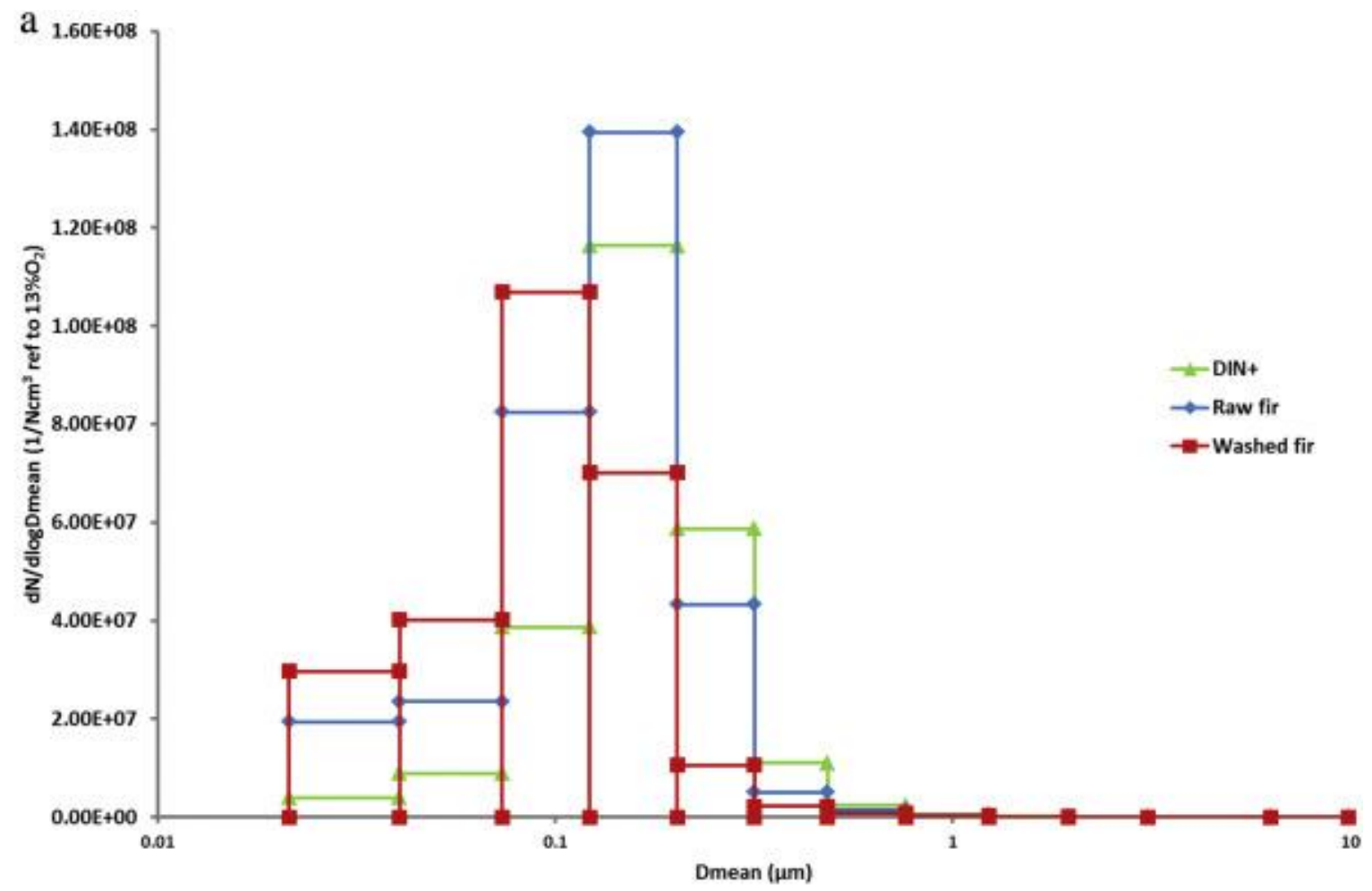




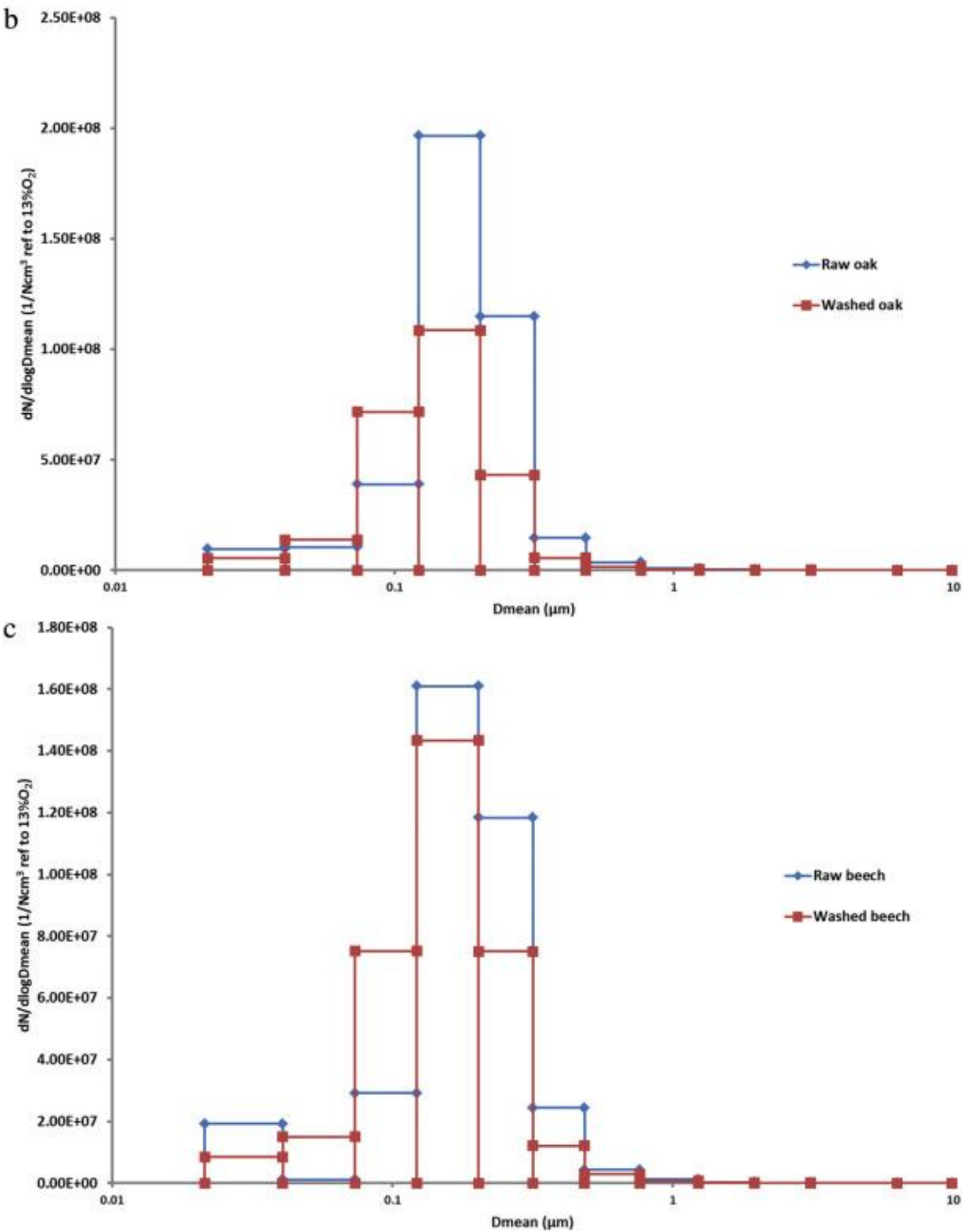

Fig. 8. Number size distribution of (a) DIN+ and both raw and washed fir (b) both raw and washed oak (c) both raw and washed beech.

The influence of the washing procedure on the particle size distribution is shown in Fig. $8 \mathrm{a}$ to $\mathrm{c}$. In the following, size number distributions of PM2.5 are presented using the mean geometric diameter (Stokes diameter) defined as the square root of the product of two continuous aerodynamic $D_{a e}$ at $50 \%$ of efficiency $\left(D_{\text {mean }}=V D_{\text {ae1 } 1} \times V D_{\text {ae2}}\right)$. Raw and washed samples present unimodal number size distributions with particle diameters centered in the range 100-200 nm. In $\mathrm{PM}_{2.5}$, nanoparticles as 
$\mathrm{PM}_{0.1}$ and $\mathrm{PM}_{0.1-1}$ largely dominate. These distribution profiles are similar to a lot of literature data and characterize biomass combustion whatever the type of fuel (logs, pellets) and the combustion device (insert, stove, boiler) $[7,59,60]$. The impact of washing wood seems to be positive regarding the total emission of particulate matter $\left(\mathrm{PM}_{2.5}\right)$. It slightly modifies the size distribution in the $\mathrm{PM}_{1}$ fractions favoring the emission of ultrafine particles $\left(\mathrm{PM}_{0.1}\right)$ in the exhaust (Table 7).

\section{Conclusions}

This work aimed to study the impact of wood washing on combustion emissions of a recent wood pellet stove. Three wood varieties, as fir, oak and beech were burned in their raw and washed form. Natural wood pellets according to the DIN CERTCO standard were also combusted as a reference during combustion tests. Particulate and gaseous emissions like $\mathrm{CO}, \mathrm{THC}, \mathrm{PAH}$, biomass tracers as phenols or sugars, and some organic compounds as BTEXT and aldehydes were measured in the fumes.

Concerning $\mathrm{CO}$, experiments show that wood washing decreases $\mathrm{CO}$ emissions, particularly in the case of oak combustion with a reduction close to $50 \%$ in comparison with raw oak. About THC emission factors all values are very low excepted for raw fir combustion, so only a decrease on fir washed wood can be observed. Regarding total PAH emissions factors, washing process decreases PAH emissions and particularly in the case of fir with a diminution up to $60 \%$. Emissions of PAH are mainly composed of light molecules with two and three aromatic rings in the gas phase whether it was washed or not.

Expressed in toxic equivalent factor, toxicity of the total PAH emissions from washed fir combustion can be reduced by $96 \%$ due to a change of aromatic rings distribution: the most toxic molecules with five aromatic rings are reduced to the benefit of 2 to 4 ring PAH which are less toxic. Furthermore, phenols and BTEXT emissions can also be reduced by the washing of biomass. Indeed, in the case of phenols emissions, phenol molecule shows a significant decrease of $91 \%$ by washing fir wood. Concerning BTEXT emissions, washed oak combustion leads to a decrease of $59 \%$ of the total of the five compounds measured. Only aldehydes and ketones emissions are significantly increased by the washing process in the case of fir and oak with an increase of respectively 33 and $60 \%$ even if a decrease of $9 \%$ is observed for beech combustion. The leaching process affects the biochemical composition of the wood, particularly the ratio of extractives that contain light molecules hardly soluble in water. The loss of extractives consequently could decrease the emissions of organic compounds during the thermal decomposition of biomass, especially during the pyrolysis phase. Due to wood demineralization, particulate emissions are reduced. Indeed, TSP values decreased for all washed biomasses and particularly for washed oak combustion with a decrease up to $50 \%$. Number particle concentrations of $\mathrm{PM}_{2.5}$ can also be reduced with a better effect on washed oak too. But even if $\mathrm{PM}_{2.5}$ are reduced, proportion of $\mathrm{PM}_{0.1}$ increased systematically for washed wood.

Finally, the washing of biomass allows the decrease in its environmental impact during its combustion in a pellet stove although the wood species plays an important role. The slight acidity of demineralized water or of the natural rain probably acts on sugars (hemicellulose and cellulose) and lignin polymers inside the wood during the treatment with modification of chemical bonding and could influence the devolatilization process during thermal treatment. Further investigations are necessary to assess this point.

\section{Acknowledgments}

The authors thank Mrs F. Proharam from the Agence De l'Environnement et de la Maitrise de l'Energie (ADEME) for the financial support of the PREPABOIS project (no 1501C0039), Sirs S. Labbé and F. Balay from LORFLAM industry and Mr N. Adam from AGRIVALOR industry. 
Appendix A. Supplementary data

Download: Download Word document (224KB)

\section{References}

[1] C. Whittaker, I. Shield, Factors affecting wood, energy grass and straw pellet durability - a review, Renew. Sust. Energ. Rev. 71 (2017) 1-11, http://dx.doi.org/10. 1016/j.rser.2016.12.119.

[2] S. Orecchio, D. Amorello, S. Barreca, II Wood pellets for home heating can be considered environmentally friendly fuels? Heavy metals determination by inductively coupled plasma-optical emission spectrometry (ICP-OES) in their ashes and the health risk assessment for the operators, Microchem. J. 127 (2016) 178-183, http://dx.doi.org/10.1016/j.microc.2016.03.008.

[3] S. Ozgen, S. Caserini, S. Galante, M. Giugliano, E. Angelino, A. Marongiu, F. Hugony, G. Migliavacca, C. Morreale, Emission factors from small scale appliances burning wood and pellets, Atmos. Environ. 94 (2014) 144-153, http://dx.doi. org/10.1016/j.atmosenv.2014.05.032.

[4] INERIS, Evaluation de l'impact des appareils de chauffage domestique à bois sur la qualité de l'air intérieur et extérieur, (2008).

[5] J. Tissari, K. Hytönen, J. Lyyränen, J. Jokiniemi, A novel field measurement method for determining fine particle and gas emissions from residential wood combustion, Atmos. Environ. 41 (2007) 83308344, http://dx.doi.org/10.1016/j.atmosenv. 2007.06.018.

[6] E. Pettersson, C. Boman, R. Westerholm, D. Boström, A. Nordin, Stove performance and emission characteristics in residential wood log and pellet combustion, part 2: wood stove, Energy Fuel 25 (2011) 315-323, http://dx.doi.org/10.1021/ ef1007787.

[7] C. Boman, E. Pettersson, R. Westerholm, D. Boström, A. Nordin, Stove performance and emission characteristics in residential wood log and pellet combustion, part 1: pellet stoves, Energy Fuel 25 (2011) 307-314, http://dx.doi.org/10.1021/ ef100774x.

[8] C. Schmidl, M. Luisser, E. Padouvas, L. Lasselsberger, M. Rzaca, C. Ramirez-Santa Cruz, M. Handler, G. Peng, H. Bauer, H. Puxbaum, Particulate and gaseous emissions from manually and automatically fired small scale combustion systems, Atmos. Environ. 45 (2011) 7443-7454, http://dx.doi.org/10.1016/j.atmosenv. 2011.05.006.

[9] F. Fachinger, F. Drewnick, R. Gieré, S. Borrmann, How the user can influence particulate emissions from residential wood and pellet stoves: emission factors for different fuels and burning conditions, Atmos. Environ. 158 (2017) 216-226, http://dx.doi.org/10.1016/j.atmosenv.2017.03.027.

[10] E.D. Vicente, M.A. Duarte, A.I. Calvo, T.F. Nunes, L. Tarelho, C.A. Alves, Emission of carbon monoxide, total hydrocarbons and particulate matter during wood combustion in a stove operating under distinct conditions, Fuel Process. Technol. 131 (2015) 182-192, http://dx.doi.org/10.1016/j.fuproc.2014.11.021.

[11] N. Pissot, Estimation de l'impact du chauffage au bois sur la qualité de l'air intérieur et extérieur: analyse de traceurs organiques spécifiques de la combustion de la biomasse au sein de l'aérosol atmosphérique, Université de Grenoble, 2011.

[12] J.S. Kinsey, P.H. Kariher, Y. Dong, Evaluation of methods for the physical characterization of the fine particle emissions from two residential wood combustion appliances, Atmos. Environ. 43 (2009) 4959-4967, http://dx.doi.org/10.1016/j. atmosenv.2009.07.008. 
[13] F. Ozil, V. Tschamber, F. Haas, G. Trouvé, The "zero-CO" domestic fireplace: a catalytic solution to reduce pollutants, Manag. Environ. Qual. 22 (2011) 429-439.

[14] M. Omara, P.K. Hopke, S. Raja, T.M. Holsen, Performance evaluation of a model electrostatic precipitator for an advanced wood combustion system, Energy Fuel 24 (2010) 6301-6306, http://dx.doi.org/10.1021/ef101031u.

[15] S. Ghafghazi, T. Sowlati, S. Sokhansanj, X. Bi, S. Melin, Particulate matter emissions from combustion of wood in district heating applications, Renew. Sust. Energ. Rev. 15 (2011) 3019-3028, http://dx.doi.org/10.1016/j.rser.2011.04.001.

[16] ADEME, Evaluation de solutions de réduction des émissions polluantes (gazeuses et particulaires) d'appareils de chauffages résidentiels alimentés à la biomasse - Etude bibliographique, (2009).

[17] ADEME, Evaluation de solutions de réduction des émissions polluantes (gazeuses et particulaires) d'appareils de chauffages résidentiels alimentés à la biomasse - Résultats de l'étude des performances de systèmes commercialisés, (2011).

[18] AFNOR, NF EN 12809/A1 - Residential Independent Boilers Fired by Solid Fuel - Nominal Heat Output up to $50 \mathrm{~kW}$ - Requirements and Test Methods, (2005).

[19] AFNOR, NF EN 13240/A2 - Poêles à combustibles solides - Exigences et méthodes d'essai, (2005).

[20] AFNOR, NF EN 14785 - Appareils de chauffage domestique à convection à granulés de bois Exigences et méthodes d'essai - Appareils de chauffage domestique à convection granulés de bois, (2006).

[21] Flamme Verte, Le label Flamme Verte : un chauffage au bois écologique, performant, économique et contemporain!, Doss. Presse, (2015).

[22] ADEME, Etude de la sensibilité des paramètres de fonctionnement des appareils de chauffage domestique au bois sur la composition et l'émission des particules fines - Etude bibliographique, (2013).

[23] S. Ozgen, S. Becagli, V. Bernardoni, S. Caserini, D. Caruso, L. Corbella, M. Dell'Acqua, P. Fermo, R. Gonzalez, G. Lonati, S. Signorini, R. Tardivo, E. Tosi, G. Valli, R. Vecchi, M. Marinovich, Analysis of the chemical composition of ultrafine particles from two domestic solid biomass fired room heaters under simulated real-world use, Atmos. Environ. 150 (2017) 87-97, http://dx.doi.org/10.1016/j. atmosenv.2016.11.048.

[24] L. Deng, T. Zhang, D. Che, Effect of water washing on fuel properties, pyrolysis and combustion characteristics, and ash fusibility of biomass, Fuel Process. Technol. 106 (2013) 712-720, http://dx.doi.org/10.1016/j.fuproc.2012.10.006.

[25] L. Jiang, S. Hu, L. Sun, S. Su, K. Xu, L. He, J. Xiang, Influence of different demineralization treatments on physicochemical structure and thermal degradation of biomass, Bioresour. Technol. 146 (2013) 254-260, http://dx.doi.org/10.1016/j. biortech.2013.07.063.

[26] D. Mourant, Z. Wang, M. He, X.S. Wang, M. Garcia-Perez, K. Ling, C.-Z. Li, Mallee wood fast pyrolysis: effects of alkali and alkaline earth metallic species on the yield and composition of bio-oil, Fuel 90 (2011) 2915-2922, http://dx.doi.org/10.1016/ j.fuel.2011.04.033.

[27] R.C. Pettersen, The chemical composition of wood, in: R. Rowell (Ed.), Chem. Solid Wood, American Chemical Society, Washington, DC, 1984, pp. 57-126, , http://dx. doi.org/10.1021/ba-19840207.ch002. 
[28] I.-Y. Eom, K.-H. Kim, J.-Y. Kim, S.-M. Lee, H.-M. Yeo, I.-G. Choi, J.-W. Choi, Characterization of primary thermal degradation features of lignocellulosic biomass after removal of inorganic metals by diverse solvents, Bioresour. Technol. 102 (2011) 3437-3444, http://dx.doi.org/10.1016/j.biortech.2010.10.056.

[29] AFNOR, NF EN 12457-2, Caractérisation des déchets - Essai de conformité pour lixiviation des déchets fragmentés et des boues - Partie 2: essai en bâchée unique avec un rapport liquide-solide de 10L/kg et une granulométrie inférieure à $4 \mathrm{~mm}$ (sans ou avec réduction de la granularité), (2002).

[30] DIN CERTCO, DIN EN 13240, Certification Scheme - Room Heaters for Solid Fuels with Lowpollution Combustion, Berlin, (2011).

[31] V.K. Verma, S. Bram, F. Delattin, P. Laha, I. Vandendael, A. Hubin, J. De Ruyck, Agro-pellets for domestic heating boilers: standard laboratory and real life performance, Appl. Energy 90 (2012) 1723, http://dx.doi.org/10.1016/j.apenergy. 2010.12.079.

[32] D.W. van Krevelen, K. te Nijenhuis, Properties of Polymers: Their Correlation with Chemical Structure; their Numerical Estimation and Prediction from Additive Group Contributions, Elsevier, 2009.

[33] S.V. Loo, J. Koppejan, The Handbook of Biomass Combustion and Co-firing, Earthscan, (2008).

[34] O. Senneca, Kinetics of pyrolysis, combustion and gasification of three biomass fuels, Fuel Process. Technol. 88 (2007) 87-97, http://dx.doi.org/10.1016/j.fuproc. 2006.09.002.

[35] D.J. Shure, P.D. Mooreside, S.M. Ogle, Rainfall effects on plant-herbivore processes in an upland oak Forest, Ecology 79 (1998) 604, http://dx.doi.org/10.2307/ 176957.

[36] P.J. Van Soest, J.B. Robertson, B.A. Lewis, Methods for dietary fiber, neutral detergent fiber, and nonstarch polysaccharides in relation to animal nutrition, J. Dairy Sci. 74 (1991) 3583-3597, http://dx.doi.org/10.3168/jds.S0022-0302(91) 78551-2.

[37] C. Yu, P. Thy, L. Wang, S.N. Anderson, J.S. VanderGheynst, S.K. Upadhyaya, B.M. Jenkins, Influence of leaching pretreatment on fuel properties of biomass, Fuel Process. Technol. 128 (2014) 43-53, http://dx.doi.org/10.1016/j.fuproc.2014.06. 030.

[38] W.M. Haynes, CRC Handbook of Chemistry and Physics, 97th Edition, CRC Press, 2016.

[39] M. Marjamäki, J. Keskinen, D.-R. Chen, D.Y.H. Pui, Performance evaluation of the electrical lowpressure impactor (ELPI), J. Aerosol Sci. 31 (2000) 249-261, http:// dx.doi.org/10.1016/S00218502(99)00052-X.

[40] N. Gauchet, J. Vendel, Modelling of the aerosol collection efficiency by drops-influence of the distance between the drops, J. Aerosol Sci. 31 (2000) 41-42, http:// dx.doi.org/10.1016/S00218502(00)90047-8.

[41] R. Tsai, L.J. Liang, Correlation for thermophoretic deposition of aerosol particles onto cold plates, J. Aerosol Sci. 32 (2001) 473-487, http://dx.doi.org/10.1016/ S0021-8502(00)00095-1.

[42] J. Zhu, S. Xia, W. Wei, H. Yu, H. W, PM2.5 removal-advances in wet collection technologies and a novel approach through temperature swing multi-phase flow, CIESC J. 64 (2013) 155-164.

[43] Hoben, Poêle à granulé à air ventilé et régulation intelligente, (2018) http://poeleshoben. fr/poele-a-granule-regulation-ventilation-sri.html , Accessed date: 16 January 2018. 
[44] P. Ravichandran, K. Corscadden, Comparison of gaseous and particle emissions produced from leached and un-leached agricultural biomass briquettes, Fuel Process. Technol. 128 (2014) 359-366, http://dx.doi.org/10.1016/j.fuproc.2014. 07.030.

[45] M. Nishimura, S. Iwasaki, M. Horio, The role of potassium carbonate on cellulose pyrolysis, J. Taiwan Inst. Chem. Eng. 40 (2009) 630-637, http://dx.doi.org/10. 1016/j.jtice.2009.05.005.

[46] T. Nussbaumer, Overview on Technologies for Biomass Combustion and Emission Levels of Particulate Matter, Zurich, (2010).

[47] Standard Norge, Norwegian Standard "Enclosed Wood Heaters. Smoke Emission, Part 2: Determination of Particulate Emission", (1994).

[48] E. Pettersson, F. Lindmark, M. Öhman, A. Nordin, R. Westerholm, C. Boman, Design changes in a fixed-bed pellet combustion device: effects of temperature and residence time on emission performance, Energy Fuel 24 (2010) 1333-1340, http:// dx.doi.org/10.1021/ef901023f.

[49] C. Peng, G. Zhang, J. Yue, G. Xu, Pyrolysis of lignin for phenols with alkaline additive, Fuel Process. Technol. 124 (2014) 212-221, http://dx.doi.org/10.1016/j. fuproc.2014.02.025.

[50] V. Tschamber, G. Trouvé, G. Leyssens, C. Le-Dreff-Lorimier, J.-L. Jaffrezo, P. Genevray, D. Dewaele, F. Cazier, S. Labbé, S. Postel, Domestic wood heating appliances with environmental high performance: chemical composition of emission and correlations between emission factors and operating conditions, Energy Fuel 30 (2016) 7241-7255, http://dx.doi.org/10.1021/acs.energyfuels.6b00333.

[51] I.-Y. Eom, J.-Y. Kim, T.-S. Kim, S.-M. Lee, D. Choi, I.-G. Choi, J.-W. Choi, Effect of essential inorganic metals on primary thermal degradation of lignocellulosic biomass, Bioresour. Technol. 104 (2012) 687694, http://dx.doi.org/10.1016/j. biortech.2011.10.035.

[52] Académie de Montpellier, LA CHIMIE DU BOIS, (2017) http://sciences-physiques. acmontpellier.fr/ABCDORGA/Famille/CHIMIEDUBOIS.html , Accessed date: 30 May 2017.

[53] D. Fengel, G. Wegener, Wood: Chemistry, Ultrastructure, Reactions, Walter de Gruyter, 1983.

[54] T. Müller, M. Müller, U. Behrendt, B. Stadler, Diversity of culturable phyllosphere bacteria on beech and oak: the effects of lepidopterous larvae, Microbiol. Res. 158 (2003) 291-297.

[55] C. Eberle, P. Gerlinger, M. Aigner, A sectional PAH model with reversible PAH chemistry for CFD soot simulations, Combust. Flame 179 (2017) 63-73, http://dx. doi.org/10.1016/j.combustflame.2017.01.019.

[56] J.D. McDonald, B. Zielinska, E.M. Fujita, J.C. Sagebiel, J.C. Chow, J.G. Watson, Fine particle and gaseous emission rates from residential wood combustion, Environ. Sci. Technol. 34 (2000) 2080-2091, http://dx.doi.org/10.1021/es9909632.

[57] B. DOORNAERT, A. PICHARD, Évaluation de la relation dose-réponse pour des effets cancérigènes: Approche substance par substance (facteurs d'équivalence toxique - FET) et approche par mélanges Évaluation de la relation dose-réponse pour des effets non cancérigènes: Valeurs Toxicologiques de Référence (VTR), (2003).

[58] Y. Ishida, K. Goto, H. Yokoi, S. Tsuge, H. Ohtani, T. Sonoda, T. Ona, Direct analysis of phenolic extractives in wood by thermochemolysis-gas chromatography in the presence of tetrabutylammonium hydroxide, J. Anal. Appl. Pyrolysis 78 (2007) 200-206, http://dx.doi.org/10.1016/j.jaap.2006.06.009. 
[59] L.S. Johansson, C. Tullin, B. Leckner, P. Sjövall, Particle emissions from biomass combustion in small combustors, Biomass Bioenergy 25 (2003) 435-446, http://dx. doi.org/10.1016/S09619534(03)00036-9.

[60] L.S. Johansson, B. Leckner, L. Gustavsson, D. Cooper, C. Tullin, A. Potter, Emission characteristics of modern and old-type residential boilers fired with wood logs and wood pellets, Atmos. Environ. 38 (2004) 4183-4195, http://dx.doi.org/10.1016/j. atmosenv.2004.04.020.

[61] J. Tissari, Fine particle emissions from residential wood combustion, Univ. Kuopio Kuopio, http://epublications.uef.fi/pub/urn_isbn_978-951-27-1090-4/urn_isbn_ 978-951-27-1090-4.pdf, (2008) , Accessed date: 7 September 2017.

[62] H. Lamberg, K. Nuutinen, J. Tissari, J. Ruusunen, P. Yli-Pirilä, O. Sippula, M. Tapanainen, P. Jalava, U. Makkonen, K. Teinilä, K. Saarnio, R. Hillamo, M.- R. Hirvonen, J. Jokiniemi, Physicochemical characterization of fine particles from small-scale wood combustion, Atmos. Environ. 45 (2011) 76357643, http://dx. doi.org/10.1016/j.atmosenv.2011.02.072.

[63] O. Sippula, K. Hytönen, J. Tissari, T. Raunemaa, J. Jokiniemi, Effect of wood fuel on the emissions from a top-feed pellet stove, Energy Fuel 21 (2007) 1151-1160, http://dx.doi.org/10.1021/ef060286e. 